\title{
Adaptive immunity in the colostrum-deprived calf: Response to early vaccination with Mycobacterium bovis strain bacille Calmette Guerin and ovalbumin ${ }^{1}$
}

\author{
B. J. Nonnecke, ${ }^{\star 2}$ W. R. Waters, $†$ J. P. Goff, ${ }^{* 3}$ and M. R. Foote $\neq$ \\ ${ }^{*}$ Ruminant Diseases and Immunology Research Unit, and \\ †Infectious Bacterial Diseases of Cattle Research Unit, USDA Agricultural Research Service, National Centers for Animal Health, \\ 1920 Dayton Rd., Ames, IA 50010 \\ łFDA, Center for Biologics Evaluation and Research, 8800 Rockville Pike, Bethesda, MD 20817
}

\begin{abstract}
Responses of the newborn calf to vaccination are frequently characterized by marginal antibody $(\mathrm{Ab})$ responses. The present study evaluated effects of colostrum ingestion on the adaptive immune response of the preruminant calf to early vaccination. Colostrumfed $(\mathrm{CF})$ and colostrum-deprived $(\mathrm{CD})$ calves were vaccinated at $2 \mathrm{~d}$ of age with Mycobacterium bovis, Pasteur strain of bacille Calmette Guerin (BCG), and ovalbumin (OVA) to track development of the adaptive immune response during the first 8 wk of life. Dams were also vaccinated with BCG prepartum. At wk 0, serum $\operatorname{IgG}_{1}, \operatorname{IgG}_{2}, \operatorname{Ig} A$, and $\operatorname{IgM}$ were elevated in $\mathrm{CF}$ calves, with $\operatorname{IgG}_{1}$ predominating. In these calves, $\operatorname{IgG}_{2}$, $\operatorname{Ig} \mathrm{A}$, and $\mathrm{IgM}$ concentrations decreased with age. The CD calves, in contrast, had very low or undetectable serum immunoglobulin concentrations at wk 0 followed by an age-related increase in $\operatorname{IgG}_{1}, \operatorname{IgG}_{2}$, and $\operatorname{IgM}$ concentrations, suggesting endogenous production of these immunoglobulin classes. Immunoblot and ELISA analyses of $\mathrm{Ab}$ response to $\mathrm{BCG}$ vaccination indicated that colostrum ingestion was associated with measurable serum anti-mycobacterial $\mathrm{Ab}$ in $\mathrm{CF}$ calves during the first month postpartum, with substantially lower levels at 7 wk of age. Although mycobacteria-specific $\mathrm{Ab}$ was undetectable in $\mathrm{CD}$ calves at wk 0 , it was present at 4 and 7 wk of age, suggesting that these calves, unlike $\mathrm{CF}$ calves, were capable of generating an $\mathrm{Ab}$ response to BCG vaccination. Antibody responses of $\mathrm{CF}$ and $\mathrm{CD}$ calves to vaccination with OVA, an antigen not present in the natural environment of dairy cattle,
\end{abstract}

Received July 8, 2011.

Accepted September 16, 2011.

${ }^{1}$ Names are necessary to report factually on available data; however, the USDA neither guarantees nor warrants the standard of the product, and the use of the name by the USDA implies no approval of the product to the exclusion of the other that may also be suitable.

${ }^{2}$ Corresponding author: brian.nonnecke@ars.usda.gov

${ }^{3}$ Current address: College of Veterinary Medicine, Iowa State University, Ames 50011. were of comparable magnitude and characterized by a progressive increase in $\mathrm{Ab}$ levels from birth (wk 0) to 7 wk of age. The disparate $\mathrm{Ab}$ responses of $\mathrm{CF}$ calves to BCG and OVA suggest that maternal antigenic experience or exposure influences $\mathrm{Ab}$ responses of the colostrum-fed preruminant calf to early vaccination. Ex vivo, antigen [OVA and M. bovis-derived purified protein derivative (PPDb)]-induced IFN- $\gamma$ and nitric oxide responses of blood mononuclear cells (PBMC) from $\mathrm{CF}$ and CD calves were comparable at wk 0 and wk 7 . As expected, responses were very low or nonexistent at wk 0 . Responses for all calves were greater at wk 7 than at wk 0 , suggesting a colostrum-independent maturation of the cell-mediated immune response capacity of the preruminant calf. The consistently greater proliferative responses of antigen-stimulated T-cell subsets at wk 7 versus wk 0 indicate the development of antigen-specific lymphocyte responses to early vaccination. Total numbers of blood leukocytes as well as numbers of lymphocytes and monocytes were unaffected by colostrum feeding; however, granulocyte numbers were higher in $\mathrm{CD}$ than in CF calves at wk 0. Granulocyte numbers decreased and monocyte numbers increased with age in all calves. Within the lymphocyte population, only natural killer $\left(\mathrm{NK}^{+}\right)$cell percentages were affected by colostrum ingestion, with higher percentages of $\mathrm{NK}^{+}$ cells in CD calves at wk 0 and wk 7. Antigen-induced proliferation of lymphocyte subsets including $\operatorname{IgM}^{+}$ cells was unaffected by colostrum ingestion. In conclusion, ingestion of colostrum within hours after birth inhibited the capacity of the calf to produce antigenspecific immunoglobulin (i.e., antibody) in response to vaccination, with little or no effect on cell-mediated immune responses. Although colostrum appeared to block endogenous antibody production, certain B-cell functions were retained. These findings will aid in development of new vaccination strategies for improving health of the preruminant calf.

Key words: preruminant calf, neonatal vaccination, colostrum deprived, bacille Calmette Guerin vaccination 


\section{INTRODUCTION}

High morbidity and mortality rates of neonatal calves attributable to infectious diseases cause substantial economic losses to producers. Recent USDAAPHIS-National Animal Health Monitoring System (NAHMS) data indicated that in 2006 the mortality rate for preweaned dairy heifers was approximately $7.8 \%$. Diarrhea or other digestive problems contributed to $56.5 \%$ of preweaned heifer calf deaths, with respiratory disease being the second largest cause of mortality (22.5\%; USDA-APHIS NAHMS, 2010). Susceptibility of the calf to infectious disease can be reduced by feeding high-quality colostrum within the first hours after birth, providing adequate nutrition during the preruminant phase of development, minimizing environmental stress during the first weeks of life, and by administering vaccines against pathogens associated with respiratory and enteric diseases. Effects of early vaccination on the adaptive immune response of the neonatal calf have not been well described. Protection afforded by early vaccination is critical given the diversity and number of potential pathogens in the calf's environment. It is generally assumed that the developmental immaturity of the immune system of the neonate, including the newborn calf, compromises the efficacy of vaccination protocols and exacerbates the calf's susceptibility to infectious disease (Siegrist, 2001; Chase et al., 2008).

The calf is born agammaglobulinemic and relies on ingestion of colostrum to ensure adequate passive immunity. The significance of colostrum in conferring protective immunity to the calf was reported almost 90 yr ago (Smith and Little, 1922). Colostrum is also a critical source of viable leukocytes, growth factors, and essential nutrients for the newborn calf. Interestingly, almost $20 \%$ of preweaned heifers demonstrate a failure of passive immunity based on serum $\operatorname{IgG}$ testing (USDA-APHIS NAHMS, 2010). Although the importance of colostrum for passive transfer of maternal immunoglobulins is well established, it has been suggested that colostral immunoglobulin, representing maternal antigenic experience, compromises the antibody $(\mathbf{A b})$ response of the preruminant calf to early vaccination (Husband and Lascelles, 1975; Aldridge et al., 1998). For example, neonatal calves fail to develop immunoglobulin responses to Brucella abortus if $\mathrm{Ag}$-specific maternal immunoglobulin is present at the time of vaccination (Husband and Lascelles, 1975). Colostrum-deprived calves, however, generate robust Ab responses to $B$. abortus. In addition, neonatal calves sensitized to an antigen to which there was no maternal immunoglobulin mount humoral responses at birth similar to that of older cattle, regardless of colostral status (Husband and Lascelles, 1975). Likewise, neona- tal calves vaccinated with Mycobacterium bovis strain bacille Calmette Guerin (BCG) failed to mount antigen (Ag)-specific humoral responses, whereas BCGvaccinated adult cattle did, suggesting that maternal $\mathrm{Ab}$ exported via colostrum may be contributory (Nonnecke et al., 2005). In contrast, functional capacities of $\mathrm{T}$ cells from BCG-vaccinated calves were similar to those of BCG-vaccinated adults and the magnitude of their cutaneous delayed-type hypersensitivity responses to intradermal administration of purified protein derivative b (PPDb) was comparable to those of vaccinated adults (Nonnecke et al., 2005). Overall, these results suggest that maternal antigenic experience does not inhibit all aspects of the adaptive response of the calf to vaccination. Other research indicates that calves given a bovine viral diarrhea (BVD) virus vaccine develop $\mathrm{Ag}$-specific $\mathrm{CD} 4^{+}, \mathrm{CD} 8^{+}$, and $\gamma \delta$ T-cell receptor $\left(\gamma \delta \mathbf{T C R}^{+}\right)$cell responses and generate memory $\mathrm{T}$ and $\mathrm{B}$ cells, despite the absence of primary Ab responses (Endsley et al., 2003, 2004). Taken together, these results suggest that although maternal immunoglobulin blocks endogenous immunoglobulin production, B cells retain other functional capacities (i.e., differentiation into memory B cells).

Foote et al. (2007) characterized the composition and function of B-cell populations from neonatal calves vaccinated at an early age with ovalbumin (OVA) and BCG. Vaccination with OVA elicited measurable OVAspecific $\mathrm{Ab}$ responses that were amplified by revaccination at 5 wk of age. Vaccination with BCG, in contrast, was not associated with increased levels of mycobacteria-specific Ab. Interestingly, $\operatorname{IgM}^{+}$lymph node-derived cells stimulated with PPDb or OVA showed increased expression of CD25 (i.e., a protein present on activated $\mathrm{B}$ and $\mathrm{T}$ cells that serves as receptor for IL-2) and CD80 (i.e., a protein found on activated B cells and monocytes that provides co-stimulatory signal for $\mathrm{T}$ cell activation), suggesting the generation of Ag-specific memory $\mathrm{B}$ cells in response to vaccination with both antigens.

The objective of the present study was to evaluate the effects of colostrum ingestion on the development of the adaptive immune response in the preruminant calf to early vaccination. Colostrum-fed (CF) and colostrum-deprived (CD) calves were vaccinated at less than $2 \mathrm{~d}$ of age with 2 antigens, Mycobacterium bovis strain BCG and OVA, to track the development of the adaptive immune response during the first 8 wk of life.

\section{MATERIALS AND METHODS}

\section{Calf Management and Treatments}

The National Animal Disease Center Animal Care and Use Committee preapproved all procedures involv- 
ing animals. Holstein bull calves $(\mathrm{n}=16)$ born to dams housed at the National Animal Disease Center were caught at birth to prevent them from suckling their dams. Calves weighing $>36.3 \mathrm{~kg}(80 \mathrm{lb})$ and without developmental problems were selected for the study. Navels were dipped in $7 \%$ iodine daily from birth to 72 $\mathrm{h}$ postpartum. Colostrum-fed calves were fed $3.8 \mathrm{~L}$ of colostrum from their dams within $4 \mathrm{~h}$ after birth.

Colostrum-deprived $(\mathrm{n}=9)$ and CF calves $(\mathrm{n}=7)$ were fed Similac infant formula (2 cans in 1.5 bottles of warm water at each feeding, Abbott Laboratories, Abbott Park, IL) twice daily for the first $48 \mathrm{~h}$ and then transitioned to a milk replacer diet. Calves were housed individually in elevated calf crates $(1.6 \mathrm{~m}$ long $\times 0.9 \mathrm{~m}$ wide $\times 0.9 \mathrm{~m}$ high $)$ in a temperature-controlled $\left(18^{\circ} \mathrm{C}\right)$ barn and fed a medicated 20\% CP and 20\% fat milk replacer (Land O'Lakes-Purina Feed, Shoreview, MN) twice daily (0700 and $1800 \mathrm{~h}$ ) following the manufacturer's recommendations. Calves were weighed weekly and the amount of milk replacer fed was adjusted at these times to allow for changes in live weight. Clean water was available between feedings. Starter grain was not fed during the study.

\section{Preparation and Administration of Vaccines}

Mycobacterium bovis BCG (Pasteur strain) and OVA vaccines were prepared as described by Foote et al. (2007). At less than $2 \mathrm{~d}$ of age, all calves were vaccinated subcutaneously in the right mid-cervical region with $1 \times 10^{7} \mathrm{cfu}$ of BCG and in the left mid-cervical region with $4 \mathrm{~mL}$ of OVA/incomplete Freund's adjuvant emulsion as described previously (Nonnecke et al., 2009). Calves were revaccinated with OVA/incomplete Freund's adjuvant 4 wk later. All dams were vaccinated with BCG approximately $60 \mathrm{~d}$ prepartum.

\section{Quantification of Serum Immunoglobulins}

Total immunoglobulins ( $\operatorname{IgG}_{1}, \operatorname{IgG}_{2}, \operatorname{IgM}$, and $\left.\operatorname{IgA}\right)$ in weekly serum samples were quantified by capture ELISA. Assays were established in ELISA-specific 96-well plates (Immunolon 2HB plates, VWR, West Chester, PA). Coating antibodies were affinity-purified sheep anti-bovine $\operatorname{IgG}_{1}, \operatorname{IgG}_{2}$, IgM, and IgA (Bethyl Laboratories, Montgomery, TX) diluted 1:100 in coating buffer (0.05 $M$ carbonate-bicarbonate, $\mathrm{pH}$ 9.6; Sigma, St Louis, MO). Calibrators consisted of bovine reference sera with defined amounts of each immunoglobulin isotype (Bethyl Laboratories) serially diluted from 15.6 to $10,000 \mathrm{ng} / \mathrm{mL}$. Standards and test sera were diluted in PBS with Tween-20 (PBST; 0.014 $M \mathrm{NaCl}, 50 \mathrm{~m} M$ Trizma, $0.05 \%$ Tween 20, pH 8.0). Detection $\mathrm{Ab}$ were sheep anti-bovine $\operatorname{IgG}_{1}, \operatorname{IgG}_{2}, \operatorname{IgM}$, or IgA conjugated to horseradish peroxidase (Bethyl Laboratories). Dilutions of each were optimized before the evaluation of test sera. SureBlue TMB Microwell Peroxidase Substrate (KPL, Gaithersburg, MD) was used as the chromogenic substrate. Plate preparation was initiated by addition of coating $\mathrm{Ab}(100 \mu \mathrm{L})$ to each well followed by $1 \mathrm{~h}$ at $22^{\circ} \mathrm{C}$. After washing 3 times with PBST, $200 \mu \mathrm{L}$ of blocking solution (PBS with $1 \% \mathrm{vol} / \mathrm{vol}$ gelatin) were added. Plates were washed 3 times and then $100 \mu \mathrm{L}$ of diluted test sera, reagent diluent only (blank), and standards were added to the appropriate wells. Plates were incubated for $1 \mathrm{~h}$ at $22^{\circ} \mathrm{C}$ and then washed 5 times with PBST. After addition of horseradish peroxidase-conjugated $\mathrm{Ab}(100 \mu \mathrm{L})$, plates were incubated $1 \mathrm{~h}$ at $22^{\circ} \mathrm{C}$ and then washed 3 times. Chromogenic substrate $(100 \mu \mathrm{L})$ was added and plates were incubated for $10 \mathrm{~min}$ at $22^{\circ} \mathrm{C}$. The enzyme-substrate reaction was stopped by addition of TMP stop solution (100 mL, KPL) to each well. Absorbance at $450 \mathrm{~nm}$ was measured using an automated plate reader (Flex Station 3, Molecular Devices, Sunnyvale, CA). Concentrations of each immunoglobulin class were determined by comparing absorbance of test samples with that of serially diluted standards within a linear curve fit. Data were corrected for dilution factor to arrive at immunoglobulin concentrations $(\mathrm{mg} / \mathrm{mL})$ in test samples.

\section{Quantification of Serum Haptoglobin}

Haptoglobin concentrations were determined as described previously (Nonnecke et al., 2009) using a bovine-specific haptoglobin ELISA (Immunology Consultants Laboratory Inc., Newberg, OR) following the manufacturer's instructions. Haptoglobin concentrations in test sera, evaluated in duplicate, were determined by comparing the absorbance of test samples with those of serially diluted standards within a linear curve fit. Data were corrected for dilution factor to arrive at haptoglobin concentrations $(\mu \mathrm{g} / \mathrm{mL})$ in test samples.

\section{Evaluation of Serum Ab Responses}

Antibody responses were evaluated using both ELISA and immunoblot analysis. Sera collected at 0 (prevaccination), 4, and 7 wk were analyzed. For ELISA, a lipoarabinomannan-enriched fraction of proteinasedigested, whole-cell sonicate of M. bovis strain 95-1315 (WCS1315), referred to as WCS1315-LAM, was prepared as described by Waters et al. (2002). Anti-OVA and anti-WCS1315-LAM specific IgG $_{1}$ levels in serum samples collected at 0,4 , and 7 wk after vaccination were determined by capture ELISA as described pre- 
viously (Foote et al., 2007) with modifications. Both assays used 96-well Immulon 2HB plates (VWR). For each sample analyzed, duplicate wells without Ag (coating buffer consisting of $0.05 \mathrm{M}$ carbonate-bicarbonate coating buffer, $\mathrm{pH}$ 9.6, $100 \mathrm{~mL}$ total volume, Sigma) and duplicate wells with $\mathrm{Ag}$ (coating buffer with WCS1315-LAM at $20 \mu \mathrm{g} / \mathrm{mL}$ or OVA at $1.56 \mu \mathrm{g} / \mathrm{mL}$ ) were prepared and incubated overnight at $4{ }^{\circ} \mathrm{C}$ in ziploc bags. Plates were washed 3 times with PBST (200 $\mu \mathrm{L} /$ well) and blocked with a commercial milk diluent blocking solution (KPL) diluted 1:20 in double deionized water and added at $200 \mu \mathrm{L} /$ well. After $1 \mathrm{~h}$ at $37^{\circ} \mathrm{C}$, plates were washed 9 times in PBST and test sera were added to wells (100 $\mu \mathrm{L} /$ well). Test sera for both assays were diluted 1:50 in PBS with $0.1 \%$ gelatin. Optimal dilutions of test sera were determined by evaluating the reactivity of undiluted sera and sera diluted from 1:10 to $1: 100$. After $20 \mathrm{~h}$ at $4^{\circ} \mathrm{C}$, plates were washed 9 times with PBST. Plates were incubated an additional $1 \mathrm{~h}$ at $37^{\circ} \mathrm{C}$ after addition of $100 \mu \mathrm{L}$ of horseradish peroxidase-sheep anti-bovine $\operatorname{IgG}_{1}$ conjugates (diluted 1:10,000 PBS/gelatin, $100 \mathrm{~mL} /$ well; Bethyl Laboratories Inc.). Plates were subsequently washed 9 times with PBST before addition of chromogenic substrate (SureBlue TMB Microwell Peroxidase Substrate, 100 $\mu \mathrm{L} /$ well; KPL). Plates were read kinetically every minute for $15 \mathrm{~min}$ at $650 \mathrm{~nm}$ using an automated plate reader (Flex Station 3, Molecular Devices). Data were analyzed using Softmax Pro software (v 5.2, Molecular Devices). Raw maximum initial rate of reaction $\left(\mathbf{V}_{\max }\right)$ was calculated by subtracting the mean $\mathrm{V}_{\max }$ (milliunits/min, $\mathrm{n}=2$ wells) of the no-Ag wells from the mean $V_{\max }$ of $\mathrm{Ag}$ wells $(n=2)$. Raw $\mathrm{V}_{\max }$ values for the positive and negative control wells also were determined. The sample-to-positive ratios $(\mathbf{S} / \mathbf{P})$ for test sera were calculated using the following formula: $\left[\mathrm{V}_{\max }\right.$ (test sample) $-\mathrm{V}_{\max }$ (negative control) $] /\left[\mathrm{V}_{\max }\right.$ (positive control) $-\mathrm{V}_{\max }$ (negative control)].

Immunoblot analysis of $\mathrm{Ab}$ responses to $\mathrm{BCG}$ vaccination was performed as described by Bannantine and Stabel (2000) with the following modifications. Antigens included M. bovis-derived WCS1315 and OVA (2 $\mathrm{mg} / \mathrm{mL}$, Sigma). Antigens were electrophoresed through preparative $12 \%$ (wt/vol) polyacrylamide gels. Electrophoretic transfer of proteins onto pure nitrocellulose was accomplished with a Bio-Rad Trans Blot cell (Bio-Rad Laboratories, Mississauga, ON, Canada) using PBS (25 mM, pH 7.8) at $0.8 \mathrm{~A}$ for 90 min. After transfer, membranes were blocked with PBST with $2 \%$ (wt/vol) BSA (PBST-BSA). Membranes were placed into a 20-slot mini-protean multi-screen device (BioRad), and serum from each calf was diluted 1:200 in PBST-BSA and added to independent slots. After $2 \mathrm{~h}$ at $22^{\circ} \mathrm{C}$ with gentle rocking, membranes were washed
3 times with PBST and incubated with peroxidaseconjugated Protein G (Sigma) diluted 1:20,000 in PBST-BSA for $1.5 \mathrm{~h}$. Membranes were washed again with PBST and developed for chemiluminescence using SuperSignal detection reagent (Pierce Chemical Co., Rockford, IL).

\section{Isolation and Enrichment of PBMC}

Peripheral blood was collected into $10 \%$ (vol/vol) 2 $\times$ acid-citrate-dextrose $(77 \mu M$ sodium citrate, $38 \mu M$ citric acid, and $122 \mu M$ dextrose) tubes and also into Vacutainers with potassium EDTA (Becton Dickinson, Franklin Lakes, NJ). Blood was collected after an overnight fasting period and before the morning feeding. Blood mononuclear cells were isolated (Nonnecke et al., 2003) and resuspended in RPMI 1640 medium (Gibco Laboratories, Grand Island, NY) with $25 \mathrm{~m} M$ HEPES buffer, L-glutamine (2 $\mathrm{mM}$, Sigma), antibiotics (100 U/ $\mathrm{mL}$ of penicillin $\mathrm{G}$ and $100 \mu \mathrm{g} / \mathrm{mL}$ of streptomycin sulfate, Sigma), 2-mercaptoethanol (50 $\mu M$, Sigma), $1 \%$ nonessential AA (Sigma), and heat-inactivated fetal bovine serum (FBS, 10\% vol/vol; Hyclone Laboratories Inc., Logan, UT).

\section{In Vitro Production and Measurement of IFN-y and Inducible Nitric Oxide}

Secretion of IFN- $\gamma$ and nitrite, the stable oxidation product of nitric oxide (NO), by nonstimulated and stimulated peripheral blood mononuclear cell (PBMC) cultures was evaluated in 96-well, flat-bottomed tissue culture plates (Immunolon). Wells were seeded with $4 \times 10^{5} \mathrm{PBMC}$ in a culture volume of $200 \mu \mathrm{L}$ (final concentration of $2 \times 10^{6}$ cells $/ \mathrm{mL}$ in culture). Culture medium consisted of supplemented RPMI 1640 (Gibco Laboratories) as described above for PBMC isolation and enrichment. Cultures were nonstimulated (medium alone), stimulated with pokeweed mitogen (PWM, 2 $\mu \mathrm{g} / \mathrm{mL}$, Sigma $)$, OVA $(10 \mu \mathrm{g} / \mathrm{mL})$ or PPDb $(10 \mu \mathrm{g} /$ $\mathrm{mL}$ ). Cultures, consisting of 6 wells for each culture condition, were incubated for $72 \mathrm{~h}$ in a humidified atmosphere at $39^{\circ} \mathrm{C}$ with $5 \% \mathrm{CO}_{2}$.

For NO-producing cultures, $\mathrm{N}^{\mathrm{G}}$-monomethyl-Larginine, a competitive inhibitor of inducible $\mathrm{NO}$ synthase, was used as a negative control. The inhibitor was added to parallel nonstimulated or stimulated cultures to verify that nitrite production was due to inducible NO synthase. Nitrite $(\mu M)$ in supernatants freshly harvested after centrifugation of plates $(400 \times$ $g, 21^{\circ} \mathrm{C}, 5 \mathrm{~min}$ ), was measured by the method of Green et al. (1982) incorporating modifications described previously (Rajaraman et al., 1998). Supernatants from cultures producing IFN- $\gamma$ were harvested and stored at 
Table 1. Primary antibodies used in the analysis of blood mononuclear cell populations from colostrum-fed and colostrums-deprived calves

\begin{tabular}{|c|c|c|c|}
\hline $\begin{array}{l}\text { Primary antibody } \\
\text { specificity }\end{array}$ & Clone $^{1}$ & Isotype & $\begin{array}{l}\text { Dilution, } \\
\mu \mathrm{g} / \mathrm{mL}\end{array}$ \\
\hline CD4 T cell & GC50A1 & $\operatorname{IgG}_{2 \mathrm{a}}$ & 15 \\
\hline CD8 T cell & CACT $80 \mathrm{C}$ & IgM & 7 \\
\hline$\gamma \delta \mathrm{TCR}^{+} \mathrm{T}$ cell & GB21A & $\operatorname{IgG}_{2 b}$ & 14 \\
\hline Natural killer cell & AKS1 & $\mathrm{IgG}_{1}$ & 7 \\
\hline $\mathrm{IgM}^{+}(\mathrm{B}$ cell $)$ & PIG45A & $\operatorname{IgG}_{2 \mathrm{~b}}$ & 7 \\
\hline $\mathrm{CD} 4^{+}$(monocyte) & CAM36A & $\operatorname{IgG}_{1}$ & 7 \\
\hline
\end{tabular}

${ }^{1}$ Primary monoclonal antibodies were from VMRD (Pullman, WA); Serotec (Raleigh, NC); and M. Estes (Sealy Center for Vaccine Development, University of Texas Medical Branch, Galveston, TX).

$-80^{\circ} \mathrm{C}$ until analyses could be performed. Interferon- $\gamma$ $(\mathrm{ng} / \mathrm{mL})$ in supernatants was measured by an IFN- $\gamma$ capture ELISA (Ametaj et al., 1996). Responses were analyzed after IFN- $\gamma$ and nitrite concentrations in nonstimulated cultures were subtracted from concentrations in stimulated cultures.

\section{Composition and Proliferative Responses of Blood Leukocyte Populations}

The composition of blood leukocyte populations at wk 0 and 7 was determined by flow cytometry using a modification of a previous method (Nonnecke et al., 2003). A $25-\mu \mathrm{L}$ aliquot of anticoagulated blood from each animal was centrifuged $(1,000 \times g$, at room temperature for $20 \mathrm{~min}$ ). Contaminating erythrocytes in recovered buffy coats were eliminated by hypotonic lysis. Recovered leukocytes were washed and resuspended in PBS containing $0.02 \% \mathrm{NaN}_{3}$ and $1 \%$ (vol/vol) FBS. Approximately $5 \times 10^{5}$ cells in PBS $(100-\mu \mathrm{L}$ aliquot) were added to each of 8 wells of a 96-well, round-bottomed microtiter plate (Sigma). Individual wells were preloaded with a $50-\mu \mathrm{L}$ aliquot of a subset of the primary monoclonal antibodies (Table 1) diluted in PBS with $0.02 \% \mathrm{NaN}_{3}$ and $1 \%$ FBS. Plates were incubated for 15 min at $22^{\circ} \mathrm{C}$ in the dark and centrifuged $(400 \times$ $g$ for $2 \mathrm{~min}$ at room temperature). The washed cells were resuspended in $50 \mu \mathrm{L}$ of fluorochrome-conjugated secondary antibodies in PBS containing $0.02 \% \mathrm{NaN}_{3}$ and $1 \% \mathrm{FBS}$. Incubation and centrifugation steps were repeated as described above. Cells were resuspended in $200 \mu \mathrm{L}$ of FacsLyse buffer (Becton Dickinson, San Jose, CA) and 10,000 cells exhibiting light-scattering properties consistent with bovine mononuclear and granulocytic leukocytes were analyzed. Markers were positioned for negative control samples to provide a background of approximately $2 \%$ and were maintained at this position for all samples. Data were acquired and analyzed using a FACScan flow cytometer and CellQuest software (Becton Dickinson). Percentages of cells staining positive for a specific marker were recorded.
Percentage data in combination with total numbers of circulating leukocytes were used to estimate numbers of cells positive for each marker.

Lymphocyte subset proliferation assays were performed as described by Foote et al. (2005). Briefly, 4 $\times 10^{7}$ PBMC were resuspended in diluent $\mathrm{C}(2 \mathrm{~mL})$ provided in the PKH67 kit (Sigma). Diluted cells were added to $1 \mathrm{~mL}$ of diluted $(4 \mu M)$ PKH67 green fluorescent dye, incubated for $5 \mathrm{~min}$, and then incubated for 1 min with $4 \mathrm{~mL}$ of inactivated FBS to adsorb excess dye and stop dye uptake. Individual wells of 96-well tissue culture plates were seeded with $2 \times 10^{5} \mathrm{PKH} 67$-stained PBMC in a total volume of $200 \mu \mathrm{L}$ (6 replicates for each treatment). Cultures were nonstimulated (medium alone), stimulated with PWM $(2 \mu \mathrm{g} / \mathrm{mL}$, Sigma $)$, stimulated with OVA (10 $\mu \mathrm{g} / \mathrm{mL}$, Sigma), or stimulated with PPDb $(10 \mu \mathrm{g} / \mathrm{mL})$. Cultures were incubated for $7 \mathrm{~d}$ at $39^{\circ} \mathrm{C}$ in a humidified atmosphere with $5 \% \mathrm{CO}_{2}$. Approximately $2 \times 10^{5}$ pooled PKH67 stained cells in 150 $\mu \mathrm{L}$ of culture medium were added to individual wells of 96-well round-bottomed microtiter plates. Stained cells were labeled with 1 of 4 phenotype makers (CD4, CD8, $\left.\gamma \delta \mathrm{TCR}, \mathrm{IgM}^{+}\right)$. Primary $\mathrm{Ab}$ used in the analyses are listed in Table 1. Antibodies $(1 \mu \mathrm{g} /$ well $)$ diluted in PBS containing $0.02 \% \mathrm{NaN}_{3}$ and $1 \%$ (vol/vol) inactivated FBS were added to individual wells in $25-\mu \mathrm{L}$ aliquots. Cells were incubated for $15 \mathrm{~min}$ at $22^{\circ} \mathrm{C}$, centrifuged, and resuspended in $100 \mu \mathrm{L}$ of secondary fluorochromeconjugated, isotype-specific Ab diluted in PBS containing $0.02 \% \mathrm{NaN}_{3}$ and $1 \%$ inactivated FBS. Cells were incubated for $15 \mathrm{~min}$ at $22^{\circ} \mathrm{C}$ in the dark, centrifuged as described above, resuspended in $200 \mu \mathrm{L}$ of PBS, and evaluated the same day by flow cytometry.

Ten thousand cells exhibiting light-scattering properties consistent with bovine PBMC were analyzed. Data were acquired using a BDLSR flow cytometer (Becton Dickinson). Lymphocyte subset proliferation data were acquired using CellQuest (Becton Dickinson) software and analyzed using Modfit LT (Verity Software House Inc., Topsham, ME) software. Proliferation profiles were determined for gated lymphocyte subsets within 
the PBMC population. Lymphocyte proliferation was estimated by measuring the fluorescence intensity of PKH67-stained cells. Because fluorescence intensity decreases progressively with the number of cell divisions, cell generation can be mathematically determined by fluorescence intensity using Modfit LT software. Data are presented as the mean $( \pm \mathrm{SEM})$ percentages of specific T-cell subsets in the first through fifth generation beyond the parent population. The cell population was considered to have proliferated if it was not in the parent generation.

\section{Cutaneous Delayed-Type Hypersensitivity Reaction}

The comparative cervical skin test, performed according to the Bovine Tuberculosis Eradication Uniform Methods and Rules (USDA-APHIS, 2005), was used to gauge the magnitude of the delayed-type hypersensitivity response elicited by BCG vaccination. This test uses biologically balanced USDA bovine and avian PPDb tuberculins. All calves were injected intradermally with $100 \mu \mathrm{L}$ of PPDb and Mycobacterium avium PPD (PPDa) at separate sites in the mid-cervical region 7 wk after BCG vaccination. Skin-fold thickness was measured before tuberculin administration and $24 \mathrm{~h}$ and $72 \mathrm{~h}$ later. Responses were analyzed after subtracting pretest skin-fold thicknesses from skin-fold thicknesses at $24 \mathrm{~h}$ and $72 \mathrm{~h}$ after antigen administration.

\section{Statistical Analyses}

Data were analyzed as a completely randomized design using Statview software (version 5.0, SAS Institute Inc., Cary, NC). Calf served as the experimental unit in the analysis of all data. Composition and proliferative responses of PBMC populations, serum antibody, and haptoglobin, and in vitro IFN- $\gamma$ and NO secretion were analyzed as a split-plot with repeated-measures ANOVA. The model included fixed effects of treatments (colostrum-fed vs. colostrum-deprived), time (week on experiment), and treatment $\times$ time interaction, and calf was included as the random effect. Fisher's protected LSD test was applied when effects detected by the model were significant $(P<0.05)$. Delayed-type hypersensitivity data were analyzed as a split-plot with factorial ANOVA. Colostrum treatment and calf were included in the model as fixed and random effects, respectively. Fisher's protected LSD test was applied when effects detected by the model were significant $(P$ $<0.05)$.

\section{RESULTS}

\section{Serum Immunoglobulin and Haptoglobin Concentrations}

Immunoglobulin concentrations in sera collected weekly from $\mathrm{CF}$ and $\mathrm{CD}$ calves are shown in Figure 1. Immunoglobulin $\mathrm{G}_{1}$ (panel a), $\operatorname{Ig}_{2}$ (panel b), IgA (panel c), and IgM (panel d) were not detectable in CD calves at wk 0; however, all isotypes were detectable in $\mathrm{CF}$ calves at wk 0 , with $\operatorname{IgG}_{1}$ predominating. At wk 0 , $\operatorname{IgG}_{1}, \operatorname{IgG}_{2}, \operatorname{Ig} \mathrm{A}$, and $\operatorname{IgM}$ concentrations in $\mathrm{CF}$ calves were $9.63,1.12,2.23$, and $1.01 \mathrm{mg} / \mathrm{mL}$, respectively. In $\mathrm{CD}$ calves, $\operatorname{IgG}_{1}$ concentrations increased $(P<0.05)$ progressively during the study and were comparable to those in $\mathrm{CF}$ calves by wk 7 . Concentrations of $\mathrm{IgG}_{2}$ in CD calves also increased $(P<0.05)$ with age and were comparable to concentrations in CF calves from wk 4 to 7. Immunoglobulin A and IgM concentrations in CF calves decreased $(P<0.05)$ progressively from their maximal concentrations at wk 0 to $\leq 0.10 \mathrm{mg} / \mathrm{mL}$ from wk 4 to 7. In CD calves, IgA and IgM concentrations remained low throughout the 7 -wk period, although IgM concentrations were marginally higher $(P<0.05)$ from wk 2 through wk 7 than at wk 0 .

Effects of colostrum deprivation on serum haptoglobin concentrations are presented in Table 2. Colostrumdeprived calves had markedly higher haptoglobin concentrations than $\mathrm{CF}$ calves from wk 1 through wk 5; however, by wk 6 and 7, haptoglobin concentrations had decreased and were comparable to those in $\mathrm{CF}$ calves.

\section{Antigen-Specific Responses to Early Vaccination with OVA and BCG}

Antibody Responses to Early Vaccination. Antibody responses elicited by vaccination with BCG

Table 2. Mean $( \pm$ SEM) serum haptoglobin concentrations $(\mu \mathrm{g} / \mathrm{dL})$ in colostrum-fed $(\mathrm{n}=7)$ and colostrum-deprived $(\mathrm{n}=9)$ calves

\begin{tabular}{lccccccc}
\hline & \multicolumn{5}{c}{ Age, ${ }^{1}$ wk } \\
\cline { 2 - 7 } Treatment & 0 & 1 & 2 & 3 & 5 & 6 & 7 \\
\hline Colostrum-fed & $0.27(0.05)$ & $0.10(0.03)$ & $0.04(0.02)$ & $0.04(0.01)$ & $0.05(0.01)$ & $0.03(0.01)$ & $0.10(0.04)$ \\
Colostrum-deprived & $5.17(4.28)$ & $28.9(10.2)^{* * *}$ & $13.19(6.90)^{*}$ & $9.04(4.55)^{*}$ & $6.77(2.79)^{*}$ & $0.18(0.06)$ & $0.18(0.07)$ \\
\hline
\end{tabular}

${ }^{1}$ Average age at wk 0 sampling time was $1.9 \mathrm{~d}( \pm 0.19 \mathrm{~d})$; average age at wk 7 sampling time was $51.1 \mathrm{~d}( \pm 0.2 \mathrm{~d})$.

${ }^{*} P<0.05$; ${ }^{* *} P<0.001$ : treatment means that differed at a specific time. 
and OVA at wk 0 were evaluated using ELISA (Figure 2) and immunoblot (Figures 3 and 4). Mycobacterial (WCS1315)-specific $\operatorname{IgG}_{1}$ levels in serum from $\mathrm{CF}$ and $\mathrm{CD}$ calves are shown in Figure 2a. At the time of vaccination (wk 0), mycobacteria-specific $\operatorname{IgG}_{1}$ was detected in $\mathrm{CF}$ calves ( $\mathrm{S} / \mathrm{P}$ ratio: 0.653 ) and was undetectable in $\mathrm{CD}$ calves. During the weeks following vaccination, mycobacteria-specific IgG $_{1}$ levels in $\mathrm{CF}$ calves decreased progressively and by wk 7 were lower $(P<0.05)$ than levels in sera collected at the time of vaccination. In contrast, mycobacteria-specific $\operatorname{IgG}_{1}$ levels in $\mathrm{CD}$ calves at wk 4 and 7 increased $(P<0.01)$ relative to wk 0 values and at wk 7 were higher than at wk 0 and wk 4 and were comparable to levels in $\mathrm{CF}$ calves. At the time of calving, mycobacteria-specific $\mathrm{IgG}_{1}$ concentrations in sera from the BCG-vaccinated dams averaged $0.626(\mathrm{SEM} \pm 0.081)$.

a.

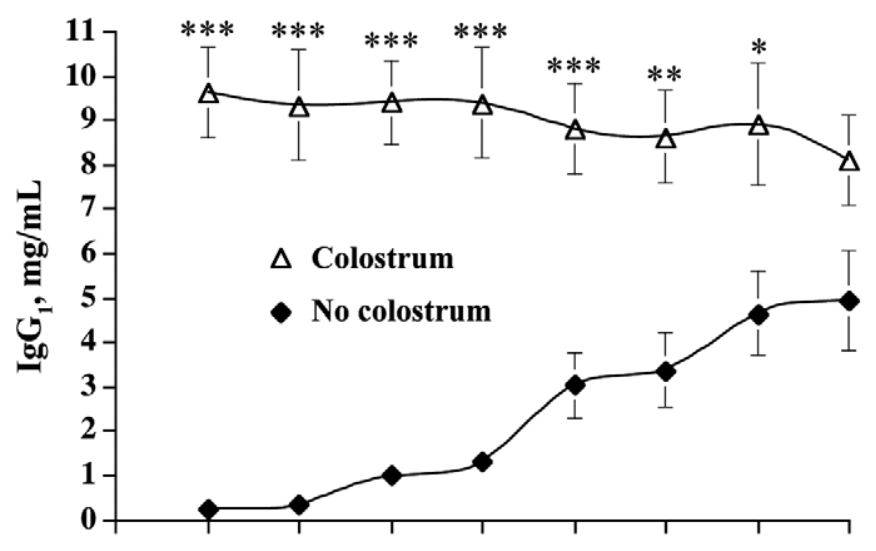

c.

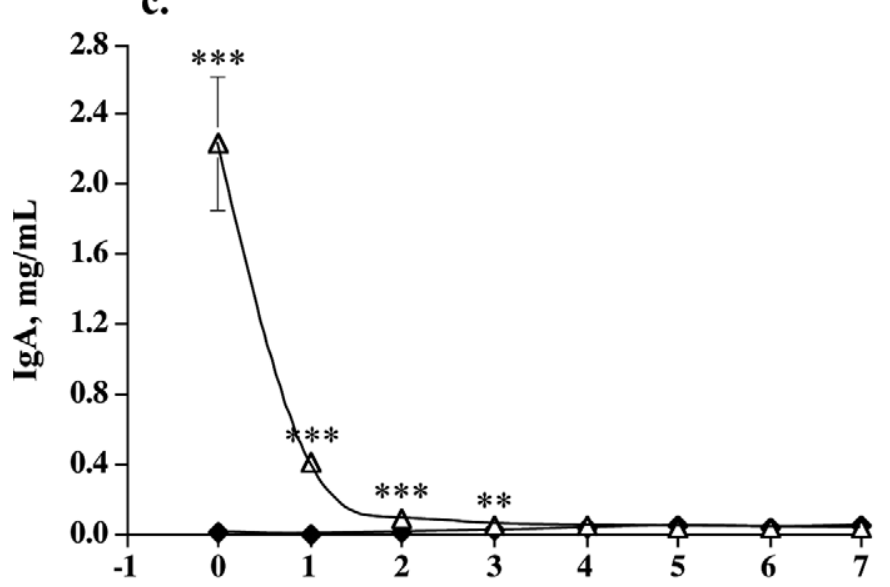

Ovalbumin-specific $\operatorname{IgG}_{1}$ levels in $\mathrm{CF}$ and $\mathrm{CD}$ calves are shown in Figure 2b. All calves had low but measurable serum OVA-specific $\operatorname{IgG}_{1}$ at the time of vaccination (wk 0). Although levels in CD calves were numerically lower than levels in CF calves at this time, these values were not different. Ovalbumin-specific $\mathrm{IgG}_{1}$ responses of $\mathrm{CF}$ and $\mathrm{CD}$ calves increased $(P<0.0001)$ between wk 0 and wk 4 and again between wk 4 and wk 7 ( $P$ $<0.0001)$. Responses of $\mathrm{CF}$ and $\mathrm{CD}$ calves were not different at wk 4 and 7 . Ovalbumin-specific $\operatorname{IgG}_{1}$ was undetectable in maternal sera at parturition (data not shown).

Immunoblot responses to WCS1315 (Figure 3) and OVA (Figure 4) by 3 representative calves demonstrate $\mathrm{Ab}$ responses to BCG and OVA vaccination. At parturition, all the dams responded to mycobacteria (Figure 3 ) in immunoblot assays (data not shown). Mycobacte-

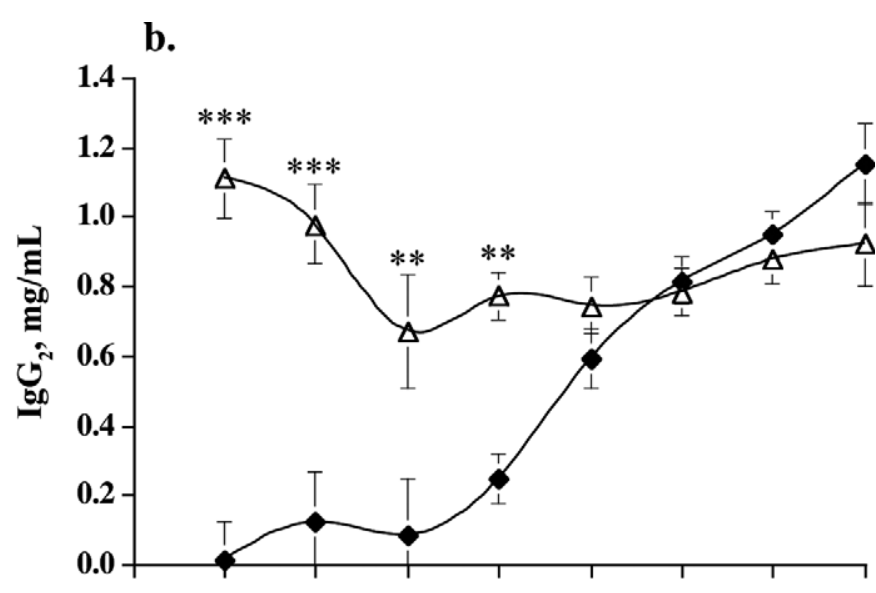

d.

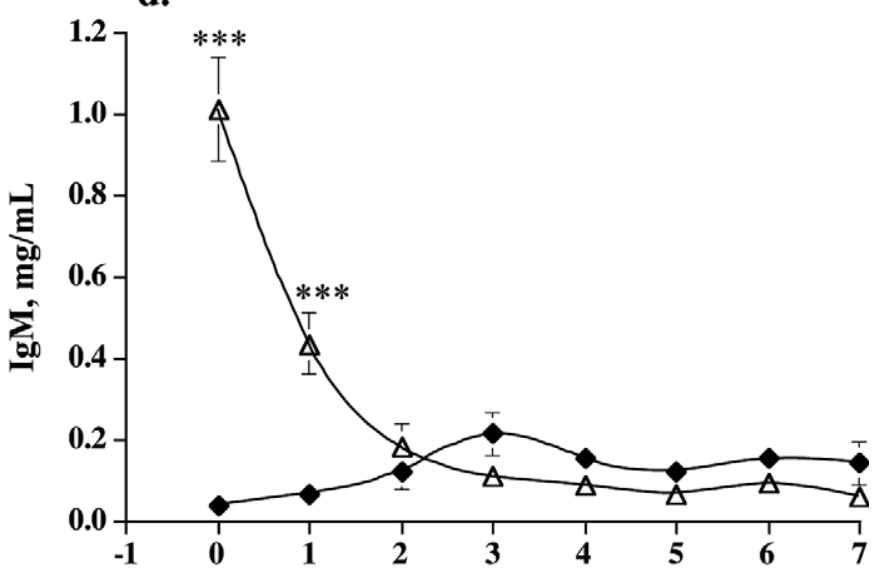

Age, wk

Figure 1. Mean $( \pm \mathrm{SEM}) \operatorname{IgG}_{1}(\mathrm{a}), \operatorname{IgG}_{2}(\mathrm{~b}), \operatorname{IgA}(\mathrm{c})$, and $\operatorname{IgM}(\mathrm{d})$ concentrations $(\mathrm{mg} / \mathrm{mL})$ in serum from colostrum-fed $(\mathrm{n}=7)$ and colostrum-deprived $(\mathrm{n}=9)$ preruminant calves. Calves were bled weekly from wk 0 (pre-vaccination) to wk 7 . Individual immunoglobulin isotypes were quantified by capture ELISA using bovine-specific reagents. Treatment means that differed at a specific time are indicated by $* P<0.05$, $* * P<0.01$, and ${ }^{* * *} P<0.001$ 

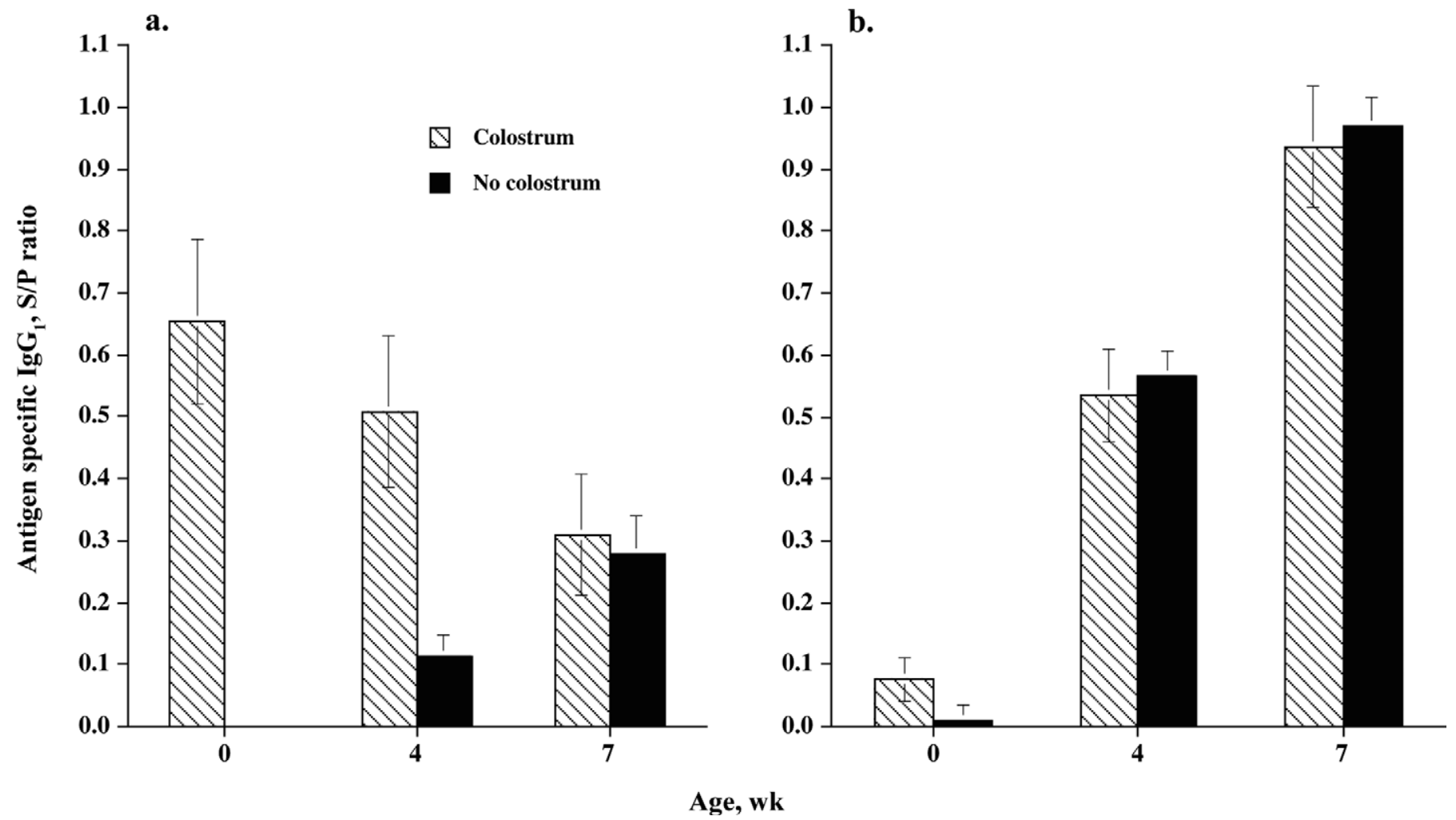

Figure 2. Mycobacteria (a) and ovalbumin (OVA, b) specific $\operatorname{IgG}_{1}$ levels in serum collected at wk 0 (pre-vaccination), wk 4 , and wk 7 from colostrum-fed $(\mathrm{n}=7)$ and colostrum-deprived calves $(\mathrm{n}=9)$ vaccinated with OVA and Mycobacterium bovis strain bacille Calmette Guerin (BCG). All calves were vaccinated with antigens shortly after birth (mean age: $1.9 \pm 0.2 \mathrm{~d}$ ) and again with OVA at $37 \mathrm{~d}( \pm 0.2 \mathrm{~d})$ of age. Mean $( \pm$ SEM) anti-OVA and anti-mycobacterium [capture antigen: lipoarabinomannan-enriched, proteinase digest of M. bovis strain 1315 (WCS1315-LAM)] $\mathrm{IgG}_{1}$ concentrations were expressed as sample-to-positive ratios (S/P) as defined in the Materials and Methods. Anti-OVA and anti-WCS-1315-LAM IgG 1 levels in maternal sera at calving were $0.013( \pm 0.006)$ and $0.626( \pm 0.081)$, respectively.

rial antibody (Figure $3 \mathrm{~b}$ ) was absent in $\mathrm{CD}$ calves at the time vaccination (i.e., wk 0), whereas all of the $\mathrm{CF}$ calves (Figure 3a) had measureable responses. Responses of $\mathrm{CF}$ calves to mycobacteria waned from 0 to 4 to $7 \mathrm{wk}$, with a few exceptions (e.g., response to $42-\mathrm{kDa}$ antigen(s) by calf 1; Figure 3a). In contrast, responses by CD calves to WCS1315 either increased (e.g., calf 16 and 18; 7 of 9 calves) or were undetectable (e.g., calf $4 ; 2$ of 9 calves) from 0 to 4 to 7 wk (Figure $3 \mathrm{~b})$. None of the CD or CF calf sera reacted to OVA at wk 0; however, responses were detectable in all calves by wk 7 and in 1 calf (i.e., calf 3 ) at wk 4 (Figure 4 ). Ovalbumin-specific Ab was not detectable in sera from dams (data not shown).

Antigen-Induced IFN- $\gamma$ and NO Secretion. Interferon- $\gamma$ responses of PBMC from $\mathrm{CF}$ and $\mathrm{CD}$ calves to both antigens (panels a and b) and PWM (panel c) are shown in Figure 5. Responses of cells from $\mathrm{CF}$ and $\mathrm{CD}$ calves to both antigens and PWM were not different $(P>0.05)$ at wk 0 or wk 7. Ovalbumin-, mycobacteria (PPDb)-, and PWM-induced IFN- $\gamma$ responses of all calves were greater at wk 7 than at wk 0
(OVA: $P<0.0001$, mycobacteria: $P=0.02$, PWM; $P<$ 0.0001). At wk 7, IFN- $\gamma$ responses of all calves to PWM exceeded $(P<0.0001)$ their responses to either Ag.

Nitric oxide responses by PBMC from $\mathrm{CF}$ and $\mathrm{CD}$ calves to both antigens (panels a and b) and PWM (panel c) are shown in Figure 6. Responses of cells from $\mathrm{CF}$ and CD calves to both antigens and PWM were not different at wk 0 or wk 7. Mitogen-induced responses by PBMC from all calves at wk 0 were comparable to responses at wk 7; however, OVA and mycobacteria responses were greater $(P<0.01)$ at wk 7 than responses at wk 0. At wk 0, PWM-induced responses of all calves exceeded their responses to either OVA $(P<0.001)$ or mycobacteria $(P=0.002)$. Responses of all calves to PWM and mycobacteria were not different at wk 7 ( $P$ $=0.07)$; however, OVA-elicited responses were weaker than responses to PWM $(P=0.01)$.

Antigen-Induced Lymphocyte Subset Proliferation. Because initial analyses of lymphocyte proliferation data indicated that treatment effects and treatment $\times$ time interactions were not significant for $\mathrm{CD}^{+}, \mathrm{CD}^{+}, \gamma \delta \mathrm{TCR}^{+}$, and $\mathrm{IgM}^{+}$lymphocyte subsets, 


\section{a. Colostrum-fed calves}

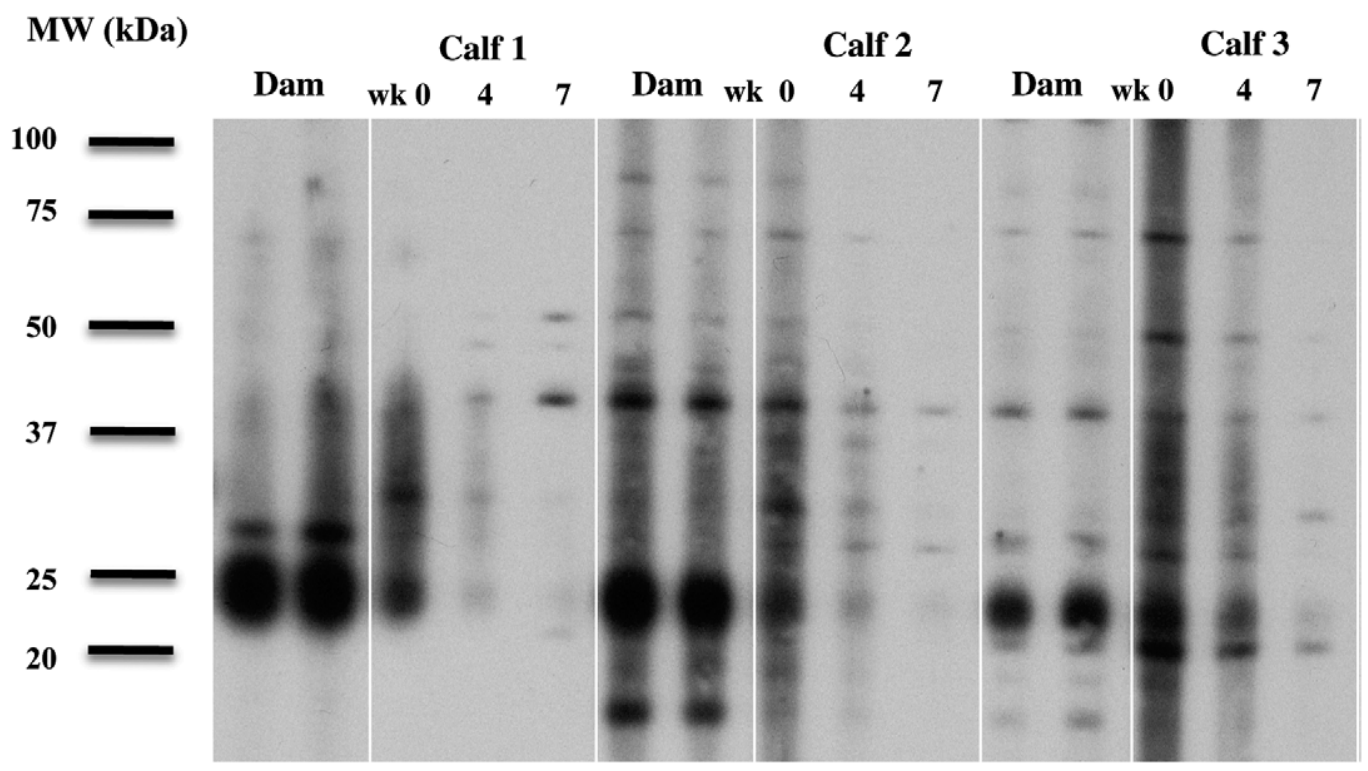

\section{b. Colostrum-deprived calves}

MW (kDa)

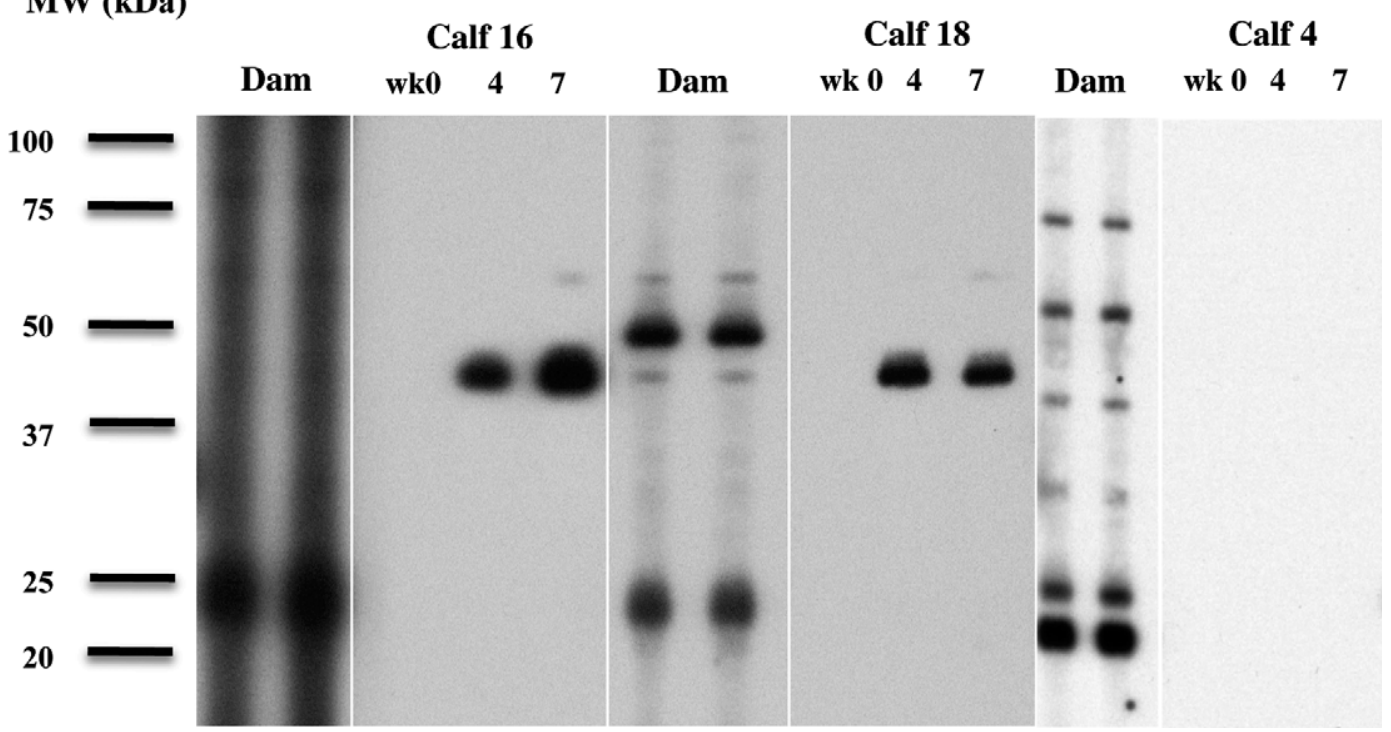

Figure 3. Immunoblots of a whole-cell sonicate of Mycobacterium bovis strain 1315 (WCS1315) probed with sera from 3 representative colostrum-fed (a) or colostrum-deprived (b) calves. Molecular mass (kDa) markers are indicated in the left margin and weeks relative to birth immediately above the blots. Responses by dams are provided immediately before the series of blots for their respective calves. Serum from dams was collected several weeks before calving (first lane) and at parturition (second lane).

proliferative responses of lymphocytes from all calves at wk 0 and at wk 7 were pooled before analysis. These data are shown in Figures 7 and 8.

Responses of $\mathrm{CD}^{+}$cells (Figure $7 \mathrm{a}$ ) to PWM at wk 0 were not different from corresponding responses at wk 7; however, percentages decreased $(P<0.0001)$ with increasing generation (i.e., number of cell divisions) at both wk 0 and wk 7 . Responses of this subset to both antigens (Figure $7 \mathrm{~b}$ and Figure $7 \mathrm{c}$ ) differed markedly from responses to PWM, a possible conse- 


\section{a. Colostrum-fed calves}

Calf 1
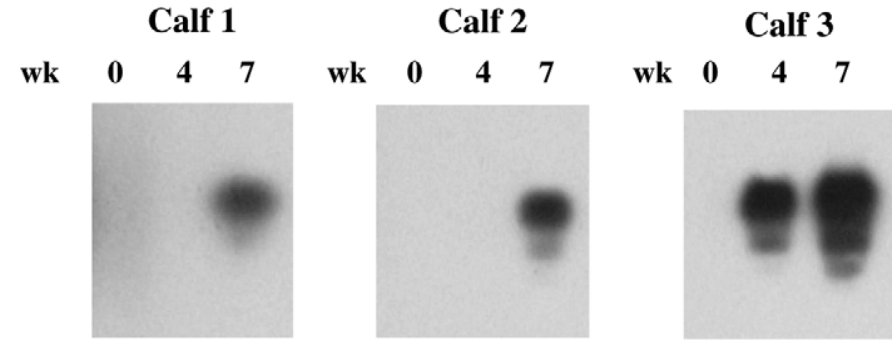

\section{b. Colostrum-deprived calves}
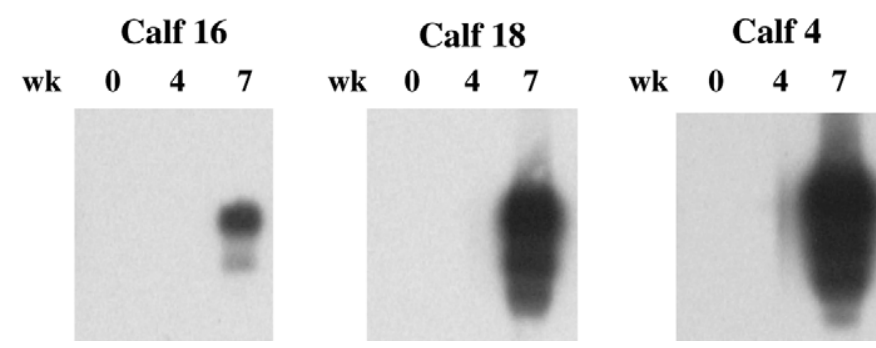

Figure 4. Immunoblots of ovalbumin (OVA) probed with sera from 3 representative colostrum-fed (a) and colostrum-deprived (b) calves collected at wk 0 (prevaccination), wk 4 , and wk 7 . Calves were vaccinated with OVA and Mycobacterium bovis strain bacille Calmette Guerin (BCG) at $1.9 \mathrm{~d}( \pm 0.2 \mathrm{~d})$ of age and again with OVA at $37 \mathrm{~d}$ $( \pm 0.2 \mathrm{~d})$ of age.

quence of the effects of early vaccination on subsequent antigen-specific reactivity of the $\mathrm{CD} 4^{+}$cell population. Unlike the responses of PWM-stimulated cells, percentages of antigen-stimulated $\mathrm{CD} 4^{+}$cells in generations 3 to 5 were very low at the time of vaccination (wk $0)$. Percentages of mycobacteria- and OVA-stimulated cells in generations 3,4 , and 5 were higher at wk 7 than percentages in the same generations at the time of vaccination (wk 0).

Responses of $\mathrm{CD}^{+}$cells (Figure $7 \mathrm{~d}$ ) to PWM were higher at wk 7 than at wk 0 . In particular, percentages of cells in generations 1 and 3 at wk 7 were greater than the corresponding percentages at wk 0 . Antigen-induced responses of this population at wk 0 and wk 7 (Figure 7e and Figure $7 \mathrm{f}$ ) followed a pattern similar to that observed for antigen-stimulated $\mathrm{CD} 4^{+}$cells. Percentages of cells in generations 2 through 5 were negligible at the time of vaccination (wk 0) and by wk 7 were detectable and greater than at wk 0 . Interestingly, percentages of antigen-induced $\mathrm{CD} 8^{+}$cells in generations 3 through 5 at wk 7 were lower $(P<0.05)$ than the corresponding percentages of antigen-stimulated $\mathrm{CD} 4^{+}$cells.

Responses of $\gamma \delta \mathrm{TCR}^{+}$cells (Figure 8a) to PWM were greater at wk 7 than at wk 0 . This difference is attributable to the significantly higher percentage in generation 1 at wk 7 than at wk 0 . Of the lymphocyte subsets examined, the $\gamma \delta \mathrm{TCR}^{+}$cells had the weakest responses to antigenic stimulation (Figure $8 \mathrm{~b}$ and Figure 8c). Although these responses were of low magnitude, the percentage of PPDb-stimulated $\gamma \delta \mathrm{TCR}^{+}$cells in generation 3 at wk 7 was higher $(P<0.05)$ than at the time of vaccination (wk 0). For OVA-stimulated cells, percentages in generation 3 and 5 were higher $(P$ $<0.05)$ at wk 7 than at wk 0 .

Responses of $\mathrm{IgM}^{+}$cells to PWM (Figure 8d) at wk 0 were not different from corresponding responses at wk 7; however, percentages of cells in generations 2 through 5 decreased $(P<0.01)$ progressively at both sampling times with the highest percentages in generation 2. Responses to PPDb and OVA are shown in Figures $8 \mathrm{e}$ and $8 \mathrm{f}$. Percentages of antigen (OVA and mycobacteria)-stimulated cells in generations 2 through 5 were higher $(P<0.05)$ at wk 7 than the corresponding percentages at the time of vaccination (wk 0). For all lymphocyte subsets, responses to PWM appeared to be limited to generations 1 through 3 . In contrast, responses to both antigens were minimal at the time of vaccination, especially in generations 3 through 5; however, by wk 7 responses were most pronounced in these generations.

Comparative Skin-Fold Test Results. Results from the comparative cervical skin-fold test performed 8 wk after BCG vaccination indicate that colostrum deprivation did not influence in vivo, antigen-specific recall responses (data not shown). Briefly, PPDb-induced responses (i.e., skin-fold thickness $(\mathrm{mm})$ as defined in Materials and Methods) of CF and CD calves at $24 \mathrm{~h}$ (5.3 vs. 5.6) and $72 \mathrm{~h}$ (8.4 vs. 9.3) were not different. Similarly, responses of CF and CD calves to PPDa were not different at 24 or $72 \mathrm{~h}$. Responses of all calves to PPDa were of lower magnitude $(P<0.05)$ than their responses to PPDb induced at $24 \mathrm{~h}(3.3$ vs. 5.5) and 72 h (5.1 vs. 8.9).

\section{Composition of Blood Leukocyte Populations}

Total numbers of circulating leukocytes in $\mathrm{CF}$ and CD calves from wk 0 to wk 7 are shown in Figure 9a. Leukocyte numbers in CF and CD calves were not different at any of the weekly time points. Leukocyte numbers in $\mathrm{CF}$ and $\mathrm{CD}$ calves during the 8 -wk period averaged $13.2( \pm 0.59)$ and $15.1( \pm 0.71) \times 10^{6} / \mathrm{mL}$, respectively, and were not different. When all calves were considered, weekly changes in leukocyte numbers were not significant.

Absolute numbers of granulocytes, lymphocytes, and monocytes in the circulation of $\mathrm{CF}$ and $\mathrm{CD}$ calves are shown in Figure 9b. At wk 0, CD calves had substantially higher numbers of granulocytes than CF calves. 

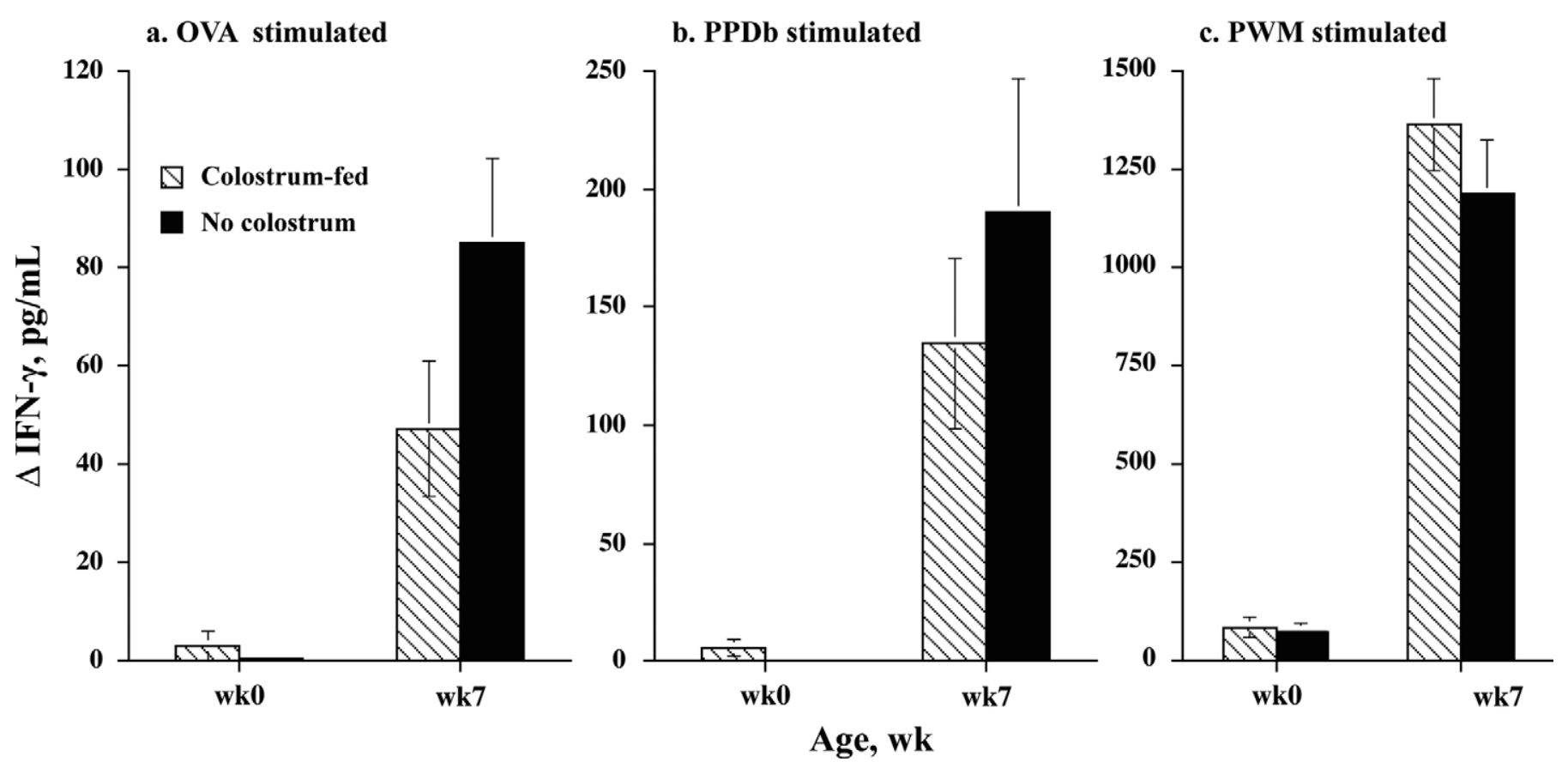

Figure 5. Mean $( \pm$ SEM) IFN- $\gamma$ concentrations in supernatants from blood mononuclear cell cultures stimulated with ovalbumin (OVA, a), Mycobacterium bovis purified protein derivative (PPDb, b), and pokeweed mitogen (PWM, c). Cells were harvested at wk 0 (prevaccination) and at $7 \mathrm{wk}$ postvaccination. Calves were vaccinated with OVA and $M$. bovis strain bacille Calmette Guerin (BCG) at $1.9 \mathrm{~d}( \pm 0.2 \mathrm{~d})$ of age and again with OVA at $37 \mathrm{~d}( \pm 0.2 \mathrm{~d})$ of age. Responses of nonstimulated cultures were subtracted from responses by parallel, stimulated cultures before data were analyzed. For each type of stimulation, responses of colostrum-fed and colostrum-deprived calves at wk 7 were greater $(P<$ $0.05)$ than their responses at wk 0.
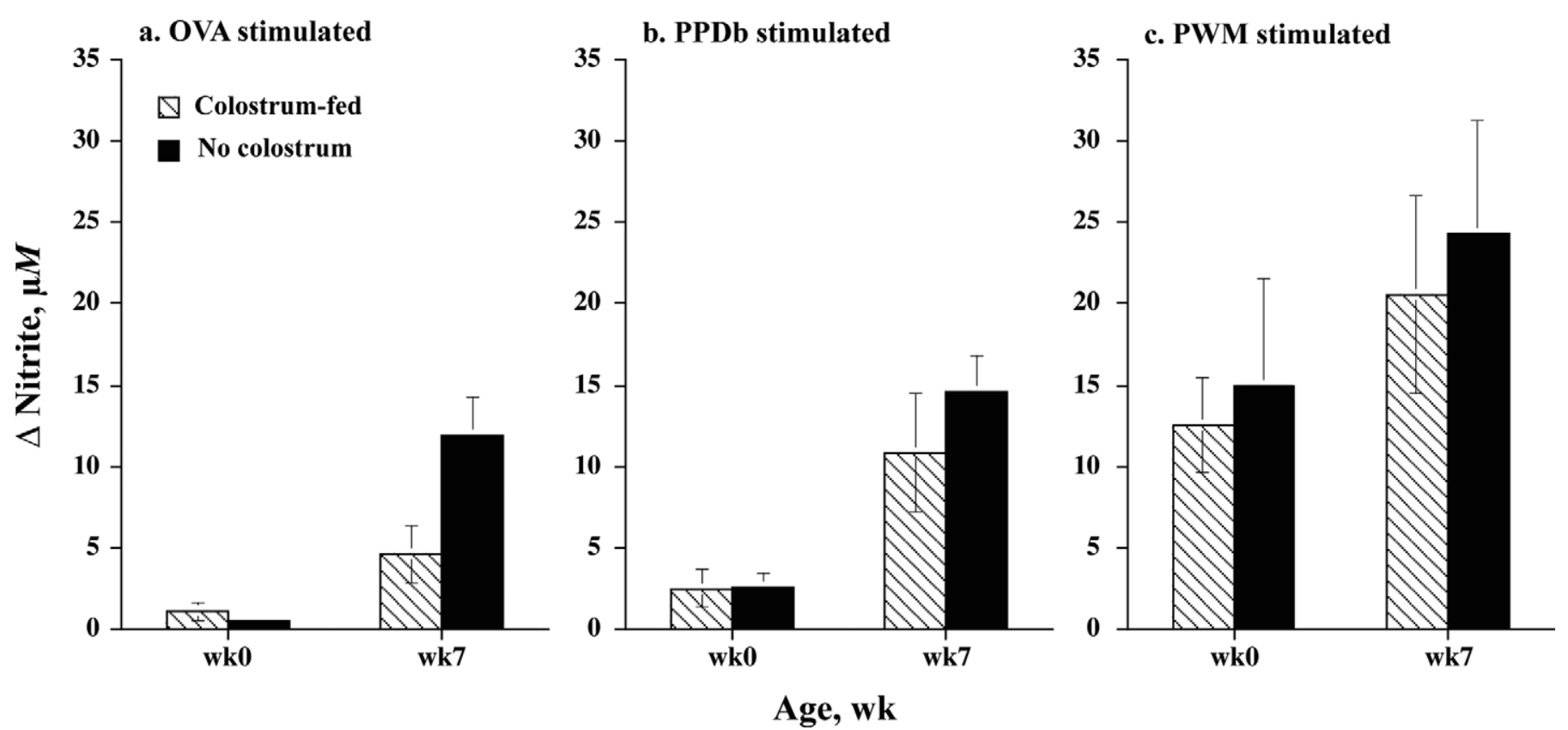

Figure 6. Mean $( \pm$ SEM) nitrite concentrations in supernatants from blood mononuclear cell cultures stimulated with ovalbumin (OVA, a), Mycobacterium bovis purified protein derivative (PPDb, b), and pokeweed mitogen (PWM, c). Cells were harvested at wk 0 (prevaccination) and at 7 wk postvaccination. Calves were vaccinated with OVA and M. bovis strain bacille Calmette Guerin (BCG) $1.9 \mathrm{~d}( \pm 0.2 \mathrm{~d})$ of age and again with OVA at $37 \mathrm{~d}( \pm 0.2 \mathrm{~d})$ of age. Responses of nonstimulated cultures were subtracted from responses by parallel, stimulated cultures before data were analyzed. 

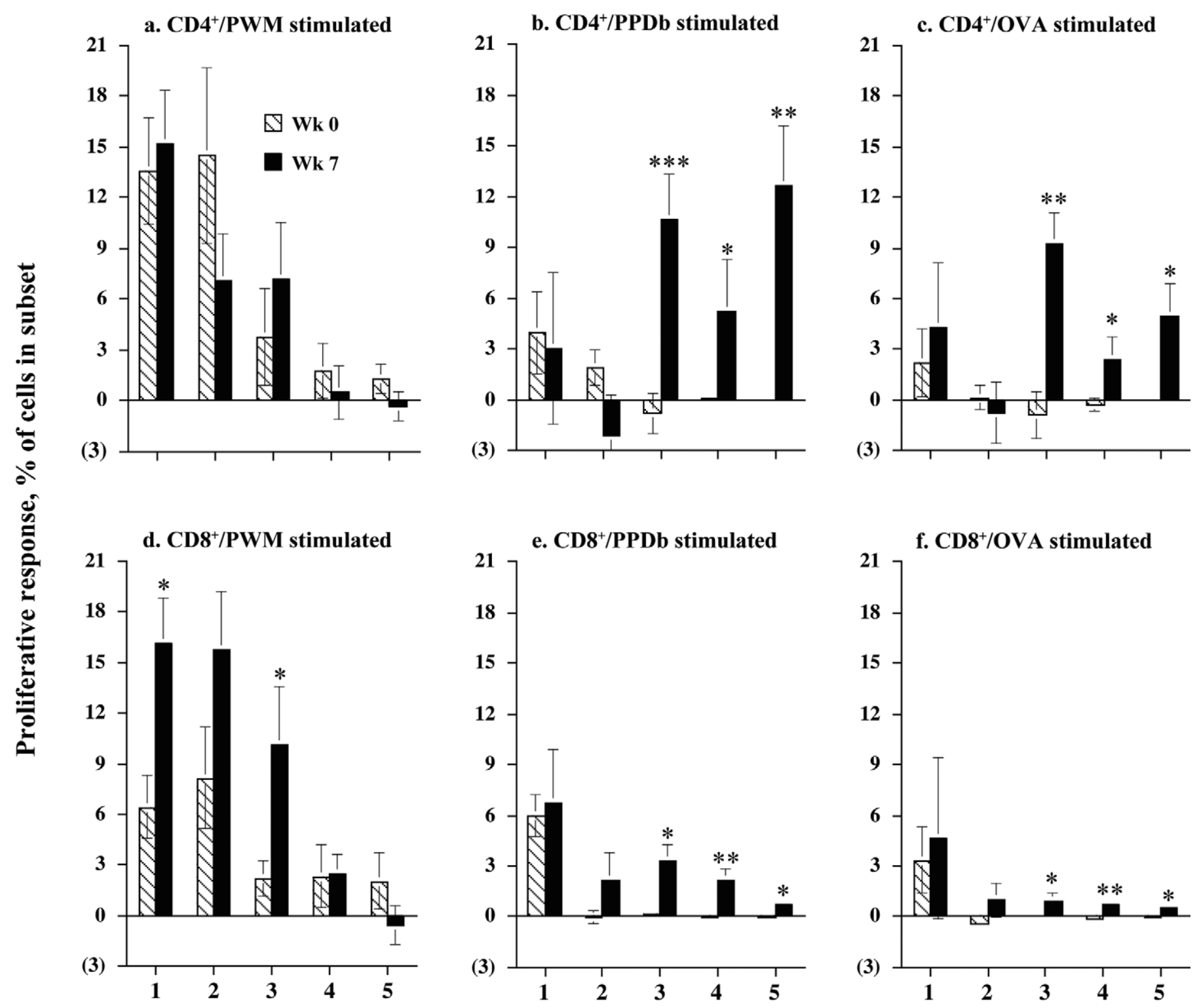

\section{Cell divisions}

Figure 7. Mean $( \pm \mathrm{SEM})$ proliferative responses of $\mathrm{CD} 4^{+}$and $\mathrm{CD} 8^{+} \mathrm{T}$ cells from all calves $(\mathrm{n}=16)$ to pokeweed mitogen $(\mathrm{PWM})$, purified protein derivative (PPDb), and ovalbumin (OVA). Blood leukocytes were harvested before vaccination (wk 0 ) and at 7 wk of age. All calves were vaccinated with both antigens at $1.9 \mathrm{~d}( \pm 0.2 \mathrm{~d})$ of age and again with OVA at $37 \mathrm{~d}( \pm 0.2 \mathrm{~d})$ of age. Data represent percentages of CD4 ${ }^{+}$ and $\mathrm{CD} 8^{+}$cells in generations 1 through 5 at the time of vaccination (wk 0) and at 7 wk of age. Before analysis, responses of non-stimulated cultures were subtracted from responses of parallel, stimulated cultures. For a specific subset, wk 0 and wk 7 percentages that differed are indicated by $* P<0.05,{ }^{* *} P<0.01$, and ${ }^{* * *} P<0.001$. Treatment effects and treatment $\times$ time interactions were not significant $(P>0.05$, data not shown) for either cell type.

Granulocyte numbers at wk 7 and lymphocyte and monocytes numbers at wk 0 and wk 7 were unaffected by colostrum deprivation. For all calves, granulocyte numbers at wk 7 were lower $(P<0.001)$ than at wk 0 . Numbers of lymphocytes and monocytes, in contrast, were higher $(P<0.05)$ at wk 7 than at wk 0 .

Percentages of $\mathrm{CD}^{+}, \mathrm{CD}^{+}, \gamma \delta \mathrm{TCR}^{+}, \mathrm{NK}^{+}$, and $\mathrm{IgM}^{+}$cells in gated lymphocyte populations from $\mathrm{CF}$ and CD calves are presented in Table 3. Of the lymphocyte subsets examined, only $\mathrm{NK}^{+}$cell percentages were affected by colostrum deprivation. The $\mathrm{CD}$ calves had higher NK cell percentages than CF calves at wk $0(P=0.04)$ and at wk 7 their NK cell percentages tended $(P=0.09)$ to be higher than those in CF calves. Although NK cell percentages in CD calves were higher $(P<0.05)$ at wk 7 than at wk 0 , those in CF calves at 
a. $\gamma \delta \mathrm{TCR}^{+} / \mathbf{P W M}$ stimulated

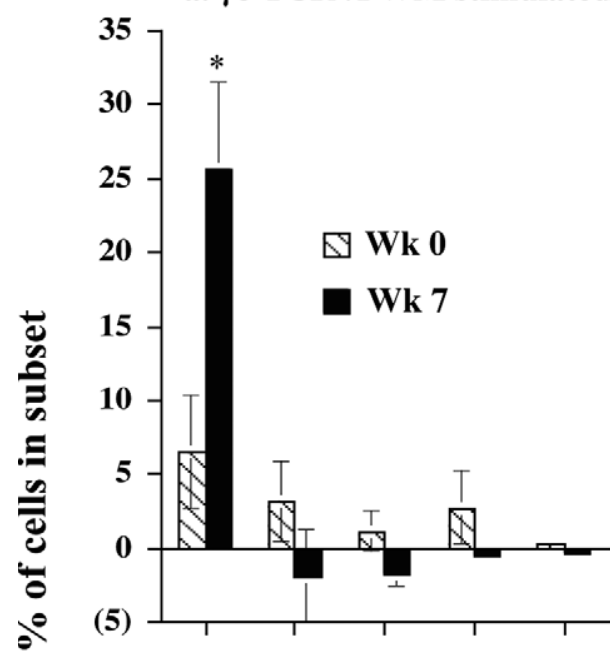

d. $\operatorname{IgM}^{+} / \mathrm{PWM}$ stimulated b. $\gamma \delta \mathrm{TCR}^{+} / \mathbf{P P D}$ stimulated

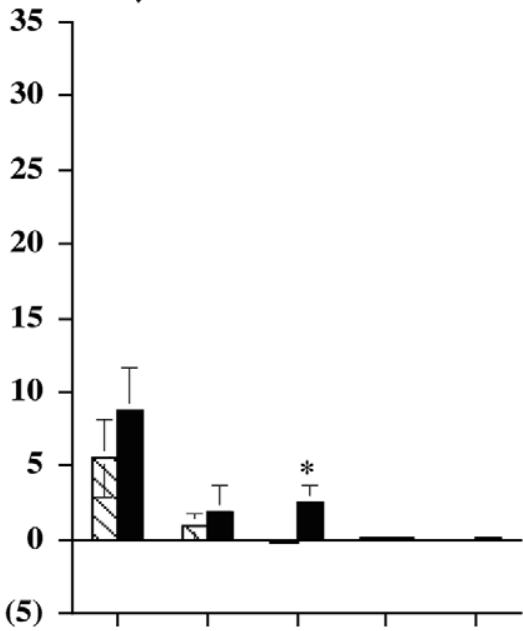

e. $\operatorname{IgM}^{+} /$PPDb stimulated

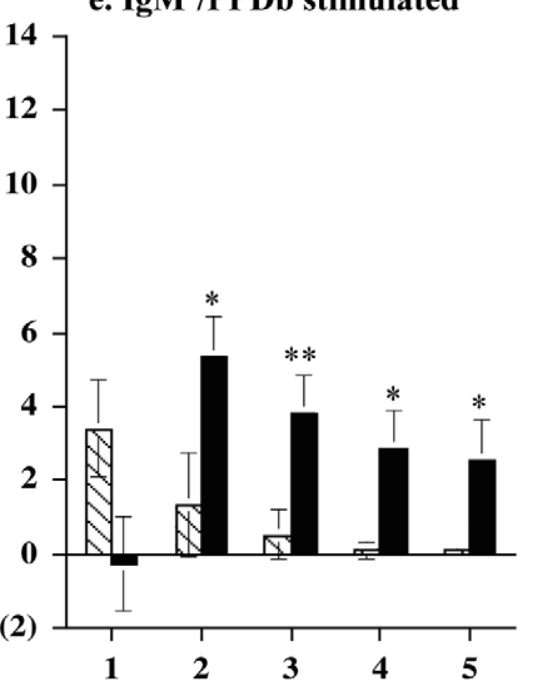

c. $\gamma \delta \mathrm{TCR}^{+} / \mathrm{OVA}$ stimulated

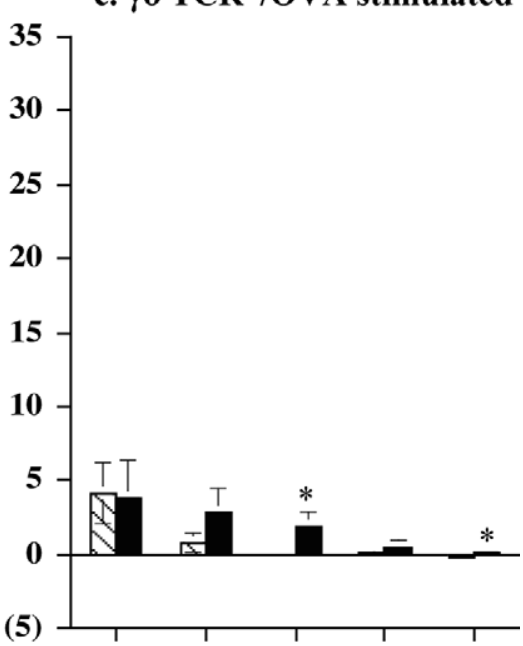

f. $\operatorname{IgM}^{+} /$OVA stimulated

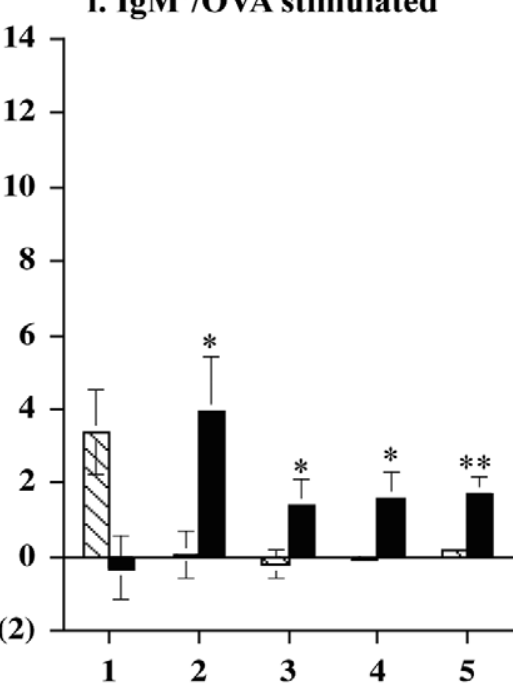

Cell divisions

Figure 8. Mean $( \pm \mathrm{SEM})$ proliferative responses of $\gamma \delta \mathrm{TCR}^{+}$and $\operatorname{IgM}^{+}$cells from all calves $(\mathrm{n}=16)$ to pokeweed mitogen $(\mathrm{PWM})$, purified protein derivative $(\mathrm{PPDb})$, and ovalbumin (OVA). Blood leukocytes were harvested from all calves before vaccination (wk 0 ) and at 7 wk of age. Data represent percentages of $\gamma \delta \mathrm{TCR}^{+}$and B cells in generations 1 through 5 before vaccination (wk 0) and at 7 wk of age. All calves were vaccinated with both antigens $1.9 \mathrm{~d}( \pm 0.2 \mathrm{~d})$ of age and again with OVA at $37 \mathrm{~d}( \pm 0.2 \mathrm{~d})$ of age. Responses of nonstimulated cultures were subtracted from responses by parallel, stimulated cultures before data were analyzed. For a specific subset, wk 0 and wk 7 percentages that differed are indicated by ${ }^{*} P<0.05$ and ${ }^{* *} P<0.01$. Treatment effect and treatment $\times$ time interactions were not significant $(P>0.05$, data not shown) for either cell type.

wk 0 and wk 7 were not different. Treatment effects, time effects, and treatment $\times$ time interactions were not significant for $\mathrm{CD}^{+}, \mathrm{CD}^{+}, \gamma \delta \mathrm{TCR}^{+}$, and $\mathrm{IgM}^{+}$ percentages.

\section{DISCUSSION}

Ingestion of colostrum within the first hours after birth provides the dairy calf with not only a complex mixture of nutrients, endocrine factors, trace minerals, and growth factors essential for gastrointestinal devel- opment and function (Blum, 2006) but also immunerelated factors (i.e., immunoglobulin, viable leukocytes, and cytokines) that afford protection against bacterial and viral infections during the first months of life. Colostral antibody, representing the antigenic experience of the dam, may also influence antibody responses of the calf to early vaccination (Husband and Lascelles, 1975; Endsley et al., 2003, Chase et al., 2008). Absorption of colostral immunoglobulin by the agammaglobulinemic newborn calf is considered adequate when 
a.

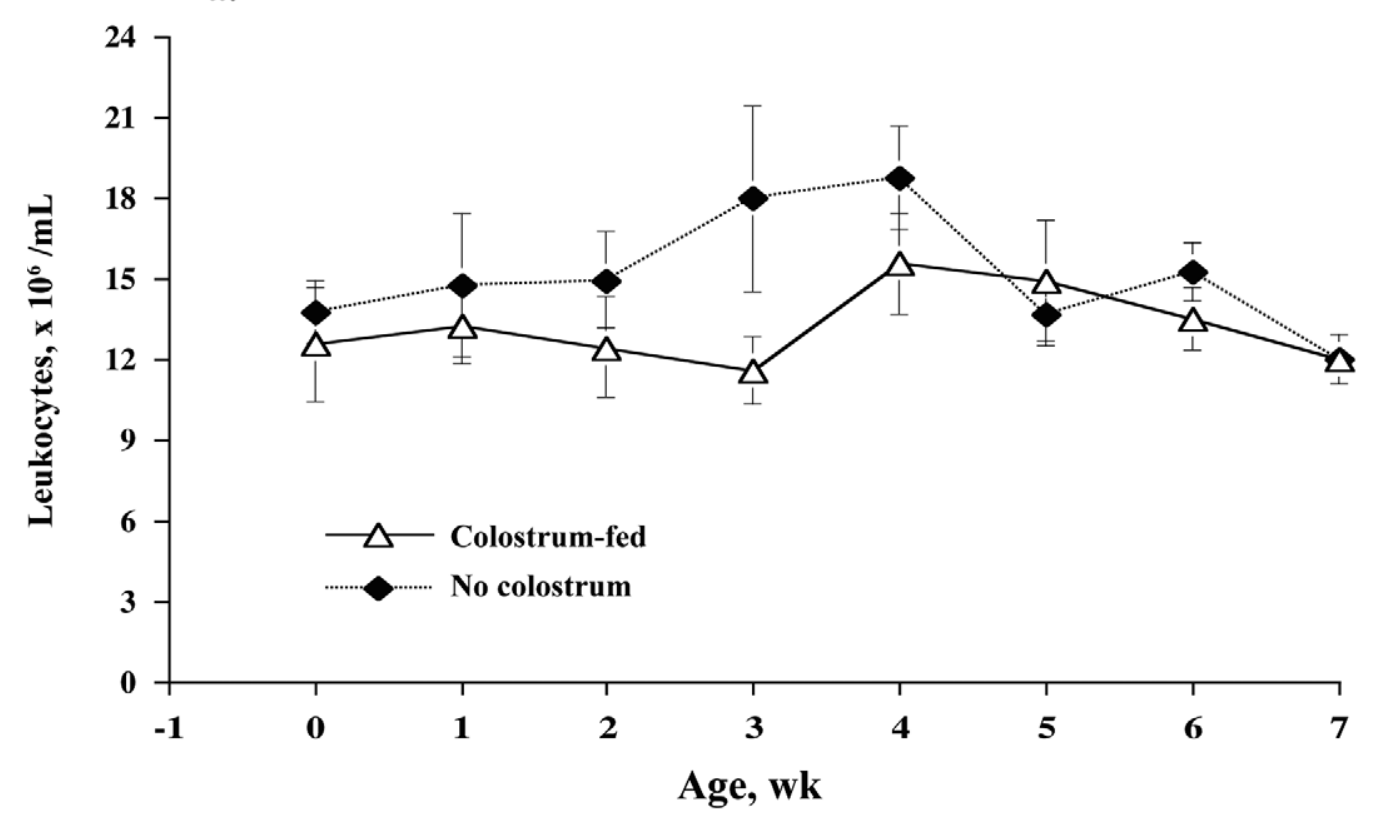

b.

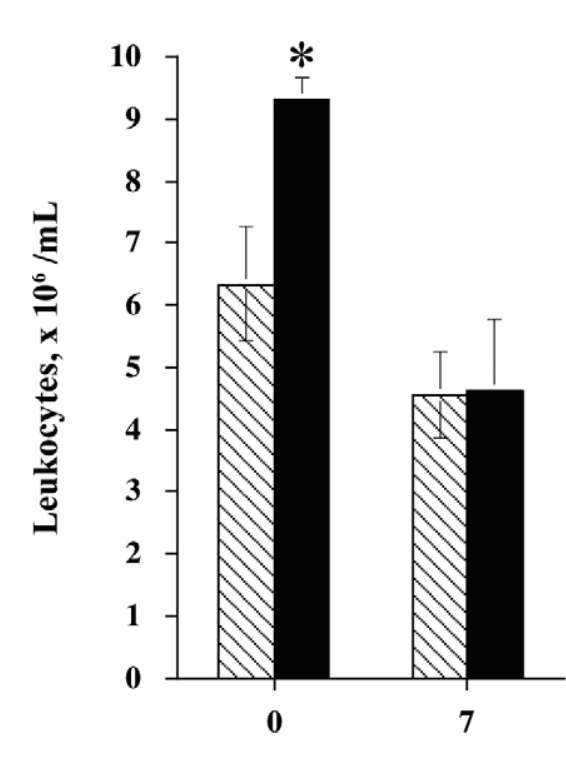

Granulocytes

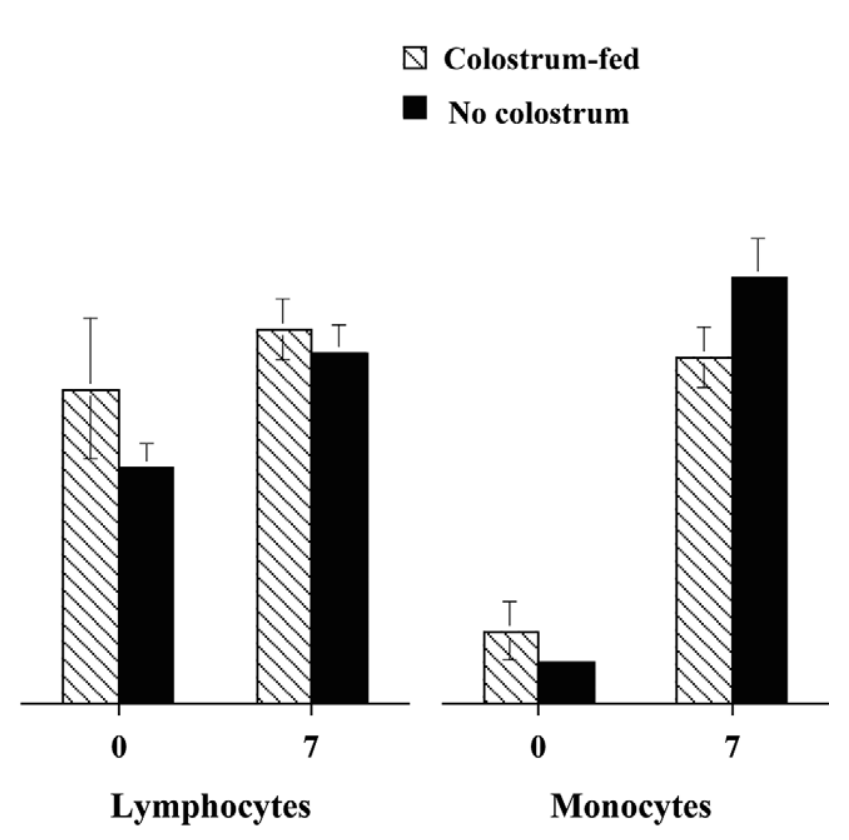

Age, wk

Figure 9. Mean $( \pm$ SEM) numbers of leukocytes in the circulation of colostrum-fed $(n=7)$ and colostrum-deprived $(n=9)$ calves $(a)$, and numbers of granulocytes, lymphocytes, and monocytes comprising the blood leukocyte population (b). Total numbers of circulating leukocytes were determined weekly, and the composition of these populations was determined at wk 0 and at wk 7 . Granulocyte, lymphocyte, and monocyte percentages were determined by flow cytometry and converted to actual numbers based on total numbers of circulating leukocytes. For a specific leukocyte subpopulation (b), treatment means that differed at a specific time are indicated by $* P<0.05$.

serum IgG concentrations, consisting predominantly of $\mathrm{IgG}_{1}$, exceed $10 \mathrm{mg} / \mathrm{mL}$ (McGuirk and Collins, 2004). This threshold concentration is associated with reduced mortality rates due to respiratory diseases and enteritis (Besser and Gay, 1994). Other immunoglobulin classes (i.e., $\operatorname{IgM}$ and $\operatorname{Ig} \mathrm{A}$ ) present in colostrum and absorbed into the circulation of the calf may also exert protective effects in the intestine and other tissues.

Results from the present study confirm the immediate positive effects of colostrum feeding not only on 
Table 3. Mean $( \pm \mathrm{SEM})$ percentages of $\mathrm{CD} 8^{+}, \mathrm{CD} 4^{+}$, and $\gamma \delta \mathrm{TCR}^{+} \mathrm{T}$ cells; B cells $\left(\mathrm{IgM}^{+}\right)$; and natural killer cells $(\mathrm{NK})$ in blood lymphocyte populations harvested from colostrum-fed $(\mathrm{n}=7)$ and colostrum-deprived $(\mathrm{n}$ $=9)$ calves at wk 0 and 7

\begin{tabular}{llrr}
\hline Cell phenotype & Treatment & Wk 0 & Wk $7^{1}$ \\
\hline $\mathrm{CD}^{+} \mathrm{T}$ cell & Colostrum-fed & $19.7(3.0)$ & $15.0(1.1)$ \\
& Colostrum-deprived & $15.7(1.5)$ & $15.0(0.7)$ \\
$\mathrm{CD}^{+} \mathrm{T}$ cell & Colostrum-fed & $15.4(2.9)$ & $16.0(1.0)$ \\
& Colostrum-deprived & $19.7(1.9)$ & $15.9(1.5)$ \\
$\gamma \delta \mathrm{TCR}^{+} \mathrm{T}$ cell & Colostrum-fed & $34.6(5.1)$ & $36.7(3.8)$ \\
& Colostrum-deprived & $38.7(1.8)$ & $32.0(2.7)$ \\
$\mathrm{NK}^{+}$cell & Colostrum-fed & $4.3(1.4)$ & $11.5(5.5)$ \\
$\mathrm{IgM}^{+} \mathrm{B}$ cell & Colostrum-deprived & $12.4(2.9)^{*}$ & $25.9(5.5)^{*}$ \\
& Colostrum-fed & $6.9(1.6)$ & $9.3(1.8)$ \\
& Colostrum-deprived & $8.5(1.3)$ & $9.0(2.1)$ \\
\hline
\end{tabular}

${ }^{1}$ Average age at wk 0 was $1.9 \mathrm{~d}( \pm 0.19 \mathrm{~d})$ and at wk 7 was $51.1 \mathrm{~d}( \pm 0.2 \mathrm{~d})$.

$* P<0.05$ : treatment means that differed at specific time.

serum $\operatorname{IgG}_{1}$ concentrations but also on $\operatorname{IgG}_{2}$, IgA, and $\operatorname{IgM}$ concentrations. Not surprisingly, $\operatorname{IgG}_{1}$ was the predominant immunoglobulin class in the circulation of $\mathrm{CF}$ calves throughout the study. Serum $\operatorname{IgG}_{2}$, IgM, and $\operatorname{Ig} \mathrm{A}$ decreased with age and by the conclusion of the study, with the exception of IgM, were similar to concentrations in the circulation of adults (Butler, 1974). Although $\operatorname{IgG}_{1}, \operatorname{IgG}_{2}, \operatorname{Ig} A$, and $\operatorname{IgM}$ were not detected in the circulation of $\mathrm{CD}$ calves at wk 0 , a pronounced increase was observed in the concentrations of $\operatorname{IgG}_{1}$ and $\mathrm{IgG}_{2}$, and to a lesser extent IgM, during the study, suggesting that immunoglobulins are produced endogenously in the preruminant calf, as reported previously (Husband et al., 1972). Previous research suggests that $\mathrm{IgG}_{1}$ and $\mathrm{IgG}_{2}$ do not reach appreciable concentrations in the CD calf until 16 to $32 \mathrm{~d}$ after birth and adult levels until 4 mo of age (Husband and Lascelles, 1975). Interestingly, $\operatorname{IgG}_{2}$ concentrations in CD calves in the present study achieved adult concentrations $(\geq 8 \mathrm{mg} /$ $\mathrm{mL}$, Butler, 1974) at approximately 1 mo of age.

In the present study, serum haptoglobin concentrations were assayed to provide an indirect method for estimating the effects of colostrum deprivation on calf health. Haptoglobin is one of several acute phase proteins produced in response to inflammatory changes associated with infection and, like serum amyloid A and C-reactive protein, has gained acceptance as a marker of systemic inflammation (Petersen et al., 2004). Haptoglobin concentrations are very low to undetectable in healthy calves and greater than $1 \mathrm{mg} / \mathrm{mL}$ during experimentally induced respiratory disease (Godson et al., 1996). The study also demonstrated strong correlations between haptoglobin concentrations and sick score (subjective clinical examination), body temperature, weight change, and plasma zinc concentration. In the present study, CD calves had markedly higher serum haptoglobin concentrations from wk 1 through wk 5 compared with CF calves. The sustained elevation in haptoglobin concentrations in $\mathrm{CD}$ calves but not $\mathrm{CF}$ calves suggests that colostrum ingestion within the first hours after birth protects against inflammatory states associated with infections typically affecting the preruminant calf. Although health data were not recorded, the attending veterinarian's observations suggested CD calves were not as healthy as CF calves during the early weeks of the study.

Although transfer of maternal $\mathrm{Ab}$ associated with the ingestion of colostrum affords the newborn calf short-term protection against a wide range of potential pathogens, these antibodies influence the development of active (i.e., adaptive) immunity in the calf vaccinated at an early age. This is reflected by the fact that $\mathrm{Ab}$ responses of the colostrum-fed calves to early vaccination frequently are impaired relative to responses in older vaccinated animals or to the responses of the fetus exposed to antigen in utero (Husband and Lascelles, 1975; Hein et al., 1988; Endsley et al., 2003; Nonnecke et al., 2005). In the present study, effects of colostrum ingestion on serum $\mathrm{Ab}$ responses of $\mathrm{CF}$ and CD calves sensitized to BCG and OVA were evaluated using ELISA and immunoblot assays. To mimic the consequences of the dam's natural antigenic exposure, all dams were vaccinated with BCG within 2 mo of parturition. Results from both assays indicated antimycobacterial $\mathrm{Ab}$ in the circulation of $\mathrm{BCG}$ vaccinated dams at the time of calving. Anti-mycobacterial Ab was also detected in the circulation of CF calves but not in CD calves, suggesting that colostral anti-mycobacterial $\mathrm{Ab}$ was absorbed into the circulation of $\mathrm{CF}$ calves. Because all ungulates are born agammaglobulinemic and derive maternal immunoglobulins solely from the ingestion of colostrum (Butler, 1974), the absence of anti-mycobacterial $\mathrm{Ab}$ in $\mathrm{CD}$ calves born to $\mathrm{BCG}$ vaccinated dams was expected. Calves also were sensitized to OVA, a benign antigen not found in the natural environment of the dairy cow. Because of these char- 
acteristics, OVA-specific Ab was not detectable or at extremely low levels in the circulation of the dams and calves at the time at parturition (dams) and before sensitization to OVA (calves), providing an opportunity to examine the $\mathrm{Ab}$ responses of calves not influenced by maternal Ab.

Historically, the role of antibody in determining the duration and severity of tuberculosis has been considered negligible. Several vaccine studies with cattle have demonstrated that T-cell central memory responses (Whelan et al., 2008) correlate negatively with mycobacterial burden (Waters et al., 2009) and tuberculosisassociated pathology (Vordermeier et al., 2009). As with T-cell central memory responses, IL-17 responses (as measured by real time reverse transcription-PCR) also appear to be associated with protection (Vordermeier et al., 2009). Antibody responses generally correlate positively to mycobacterial-elicited pathology (Lyashchenko et al., 2004) elicited by infection by $M$. bovis; however, antibody elicited by BCG vaccination has not been correlated to vaccine efficacy. In contrast, research by Glatman-Freedman (2006) suggests that mycobacteria-specific antibodies can modify various aspects of the infection process during tuberculosis, ultimately benefiting the host. Results from both ELISA and immunoblot assays indicate that colostrum ingestion influences $\mathrm{Ab}$ responses of BCG-vaccinated calves. Serum anti-mycobacterial Ab in CF calves, present at relatively high levels at wk 0 , declined progressively during the study, indicating that endogenous $\mathrm{Ab}$ synthesis was not elicited in CF calves following BCG vaccination at wk 0 . The decline may reflect the half-life (11-16 d) of colostral-derived Ab in the neonate (Husband et al., 1972; Sasaki et al., 1976). In a related study (Nonnecke et al., 2005), preruminant calves vaccinated at $7 \mathrm{~d}$ postpartum with BCG failed to mount a measurable $\mathrm{Ab}$ response, whereas $\mathrm{BCG}$-vaccinated steers had a pronounced $\mathrm{Ab}$ response (characterized by $\mathrm{Ab}$ in serum and in supernatants from antigen-stimulated PBMC cultures). Although serum Ab was absent in $\mathrm{CD}$ calves at wk 0, it was detected at wk 4 and 7 after vaccination, with the highest level occurring at wk 7 , suggesting that the calf can produce an $\mathrm{Ab}$ to early vaccination when the inhibitory effects of colostrum, possibly associated with maternal $\mathrm{Ab}$ recognizing vaccinal antigens, are absent.

Results from ELISA and immunoblot assays indicated that $\mathrm{Ab}$ responses of $\mathrm{CF}$ and $\mathrm{CD}$ calves to OVA sensitization were comparable throughout the study, with very low amounts of $\mathrm{Ab}$ present at the time of vaccination (wk 0) followed by progressive increase in anti-OVA Ab in both groups during the postvaccination period. Because OVA-specific Ab were not detected in the maternal serum at the time of parturition and $\mathrm{CF}$ calves $\mathrm{Ab}$ responses were robust, these results suggest that when maternal $\mathrm{Ab}$ are absent in colostrum the newborn calf can generate a vigorous humoral response to a protein antigen. This contention is supported by previous research (Husband and Lascelles, 1975) demonstrating that the neonate possesses the capacity to produce $\mathrm{Ab}$ to antigens not present in the natural environment of dairy cattle. Second, these data suggest that failure of the calf to mount measurable $\mathrm{Ab}$ responses to specific antigens is not necessarily due to immunological immaturity during the first weeks of life but rather due to the nature of the antigen and whether the dam's immunological experience in the form of colostral $\mathrm{Ab}$ is exported to the newborn calf within hours after birth.

Previous studies suggest that other aspects of the adaptive immune response are not compromised to the same degree by colostrum ingestion as endogenous $\mathrm{Ab}$ synthesis. Endsley et al. (2003) evaluated the effects of maternal $\mathrm{Ab}$ on humoral and $\mathrm{T}$ cell responses of calves with high levels to BVD virus (BVDV). Results indicate that calves with high levels of Ab to BVDV 1 and BVDV 2 and challenged with virulent BVDV at 2 to 5 wh of age develop pronounced BVDV-specific $\mathrm{CD}^{+}, \mathrm{CD}^{+}$, and $\gamma \delta \mathrm{TCR}^{+}$T-cell responses to challenge. Vaccination with a modified-live BVDV vaccine when high levels of maternal $\mathrm{Ab}$ are present induces antigen-specific T-cell responses and protection against experimental infection. Primates with high levels of preexisting antibodies have minimal responses to active immunization with an attenuated respiratory syncytial virus vaccine; however, when subsequently challenged with a wild strain of respiratory syncytial virus they had enhanced antibody responses that exceeded those of animals vaccinated without pre-existing passively acquired antibody (Crowe, 2001). Taken together, these results suggest that vaccinating neonates with measurable amounts of circulating maternal $\mathrm{Ab}$ can induce memory $\mathrm{T}$ and $\mathrm{B}$ cells that may influence host responses to subsequent challenge.

With regard to the responses of newborn calves to BCG vaccination, Buddle et al. (2003) demonstrated that colostrum-fed calves vaccinated with BCG within $8 \mathrm{~h}$ of birth (when cellular immune responses to antigens of environmental mycobacteria are not detectable) had vigorous in vitro antigen-specific IFN- $\gamma$ and IL-2 responses, antigen-responsive $\mathrm{CD} 4^{+}, \mathrm{CD} 8^{+}$and $\gamma \delta \mathrm{TCR}^{+} \mathrm{T}$ cell populations, and a high level of immunity when challenged with virulent $M$. bovis at 14 to 17 wk of age. In a related study (Nonnecke et al., 2005), BCG vaccination of colostrum-fed newborn dairy calves elicited adult-like responses in ex vivo assays evaluating antigen-induced T-cell subset proliferation and antigen-induced IFN- $\gamma$, NO, and tumor necrosis factor- $\alpha$ secretion. In addition, cutaneous responses of 
vaccinated calves and adults to intradermal injection of $\mathrm{PPDb}$ were pronounced and comparable, demonstrating the capacity of the young calf to develop a robust cell-mediated immune response.

Results confirm that the colostrum-fed preruminant calf is capable of generating robust cell-mediated immune responses to early vaccination. Responses of $\mathrm{CF}$ and $\mathrm{CD}$ calves to vaccination with BCG and OVA at $<2 \mathrm{~d}$ of age were estimated by considering the effects of antigen- and mitogen-induced stimulation on cell functions associated with cell-mediated immunity (i.e., IFN- $\gamma$ and NO secretion) and on the proliferation of peripheral blood T-cell subsets and B cells. The T/NK cell cytokine, IFN- $\gamma$, is produced during tuberculosis and is required for a protective response to this pathogen (Flynn and Chan, 2001). It plays a pivotal role in the activation of macrophages resulting in production of NO, a major contributor to the enhanced antimicrobial activity of the macrophage during active infections.

In the present study, Ag-specific IFN- $\gamma$ and NO responses were evaluated at the time of vaccination and at $7 \mathrm{wk}$ postvaccination. The magnitude of $\mathrm{PPDb}$ - and OVA-induced IFN- $\gamma$ and NO responses of $\mathrm{CF}$ and $\mathrm{CD}$ calves were of similar magnitude at the time of vaccination and 7 wk later, suggesting that Ag-induced IFN- $\gamma$ and NO responses of vaccinated calves were not influenced by colostrum ingestion or deprivation. The markedly higher Ag-elicited IFN- $\gamma$ and NO responses of cells from both CF and CD at wk 7 relative to levels produced at wk 0 provide functional indication of a memory T-cell response generated by early vaccination. Previous studies (Rajaraman et al., 1997, 1998) indicate that stimulated IFN- $\gamma$ and $\mathrm{NO}$ responses of PBMC from newborn calves are not as vigorous as those of adult PBMC, possibly due to the immunological immaturity of the newborn calf. Responses to PWM, a polyclonal stimulator of bovine lymphocyte function (Franklin et al., 1994), were also evaluated in both assays and served as a positive control for PBMC activity in these assays and the subset proliferation assays discussed below. Responses to PWM, lower at wk 0 than wk 7, support the contention that functional capacities of PBMC may be less developed in newborn calf.

Antigen (OVA and PPDa)-induced proliferation of $\mathrm{CD}^{+}, \mathrm{CD}^{+}$, and $\gamma \delta \mathrm{TCR}^{+}$cells as well as $\mathrm{IgM}^{+}$cells was comparable in $\mathrm{CF}$ and $\mathrm{CD}$ calves at the time of vaccination and $7 \mathrm{wk}$ after vaccination. Vaccine reactivity of these populations has been demonstrated in vaccinated, colostrum-fed newborn calves even when evidence of antibody production is absent (Endsley et al., 2003; Nonnecke et al., 2005; Foote et al., 2007). When considering all calves, responses to both antigens were more vigorous at $7 \mathrm{wk}$ postvaccination than at the time of vaccination. Responses of $\mathrm{T}$ subsets and $\mathrm{B}$ cells to both PPDb and OVA were characterized by higher percentages of cells in generation 2 or higher at wk 7 than at wk 0 , likely indicative of the development of an Ag-specific memory response to early vaccination. Evidence of priming of the lymphocyte population in the newborn calf following early vaccination may provide a basis for appropriate (i.e., protective) future responses. This contention is supported by a recent study (Waters et al., 2009) indicating that the development of memory T-cell responses because of vaccination of the newborn with BCG and newer TB vaccines (i.e., M. bovis $\Delta$ RD1 vaccine) is associated with reduced pathology or disease severity associated with subsequent experimental challenge. Buddle et al. (2003) also demonstrated that BCG vaccination of calves within $8 \mathrm{~h}$ after birth was associated with activation of $\mathrm{CD}^{+}, \mathrm{CD}^{+}$, and $\gamma \delta \mathrm{TCR}^{+} \mathrm{T}$ cells and high degree of protection against development of lung pathology induced by challenge with virulent $M$. bovis at 6 wk of age. The B-cell $\left(\operatorname{IgM}^{+}\right)$ populations in all calves were essentially unresponsive to antigen stimulation at the time of vaccination with very low percentages of cells in generations 2 through 5. By 7 wk postvaccination, responses to both antigens were characterized by marked increases in percentages in these generations, indicating that vaccination of the newborn calf promotes antigen-specific reactivity of this lymphocyte population. In a related study, Foote et al. (2007) showed increased antigen-induced expression of activation antigens on $\mathrm{B}$ cells from vaccinated preruminant calves. Although not evaluated in the present study, it would be informative to determine if enhanced antigen-specific B-cell responses postvaccination are associated with increased $\mathrm{Ab}$ production elicited by virulent $M$. bovis in the absence of maternal Ab.

Cutaneous delayed-type hypersensitivity responses of $\mathrm{CD}$ and $\mathrm{CF}$ calves to intradermal injection of PPDa or PPDb were comparable when evaluated 8 wk after vaccination. The more robust response of both $\mathrm{CF}$ and $\mathrm{CD}$ calves to $\mathrm{PPDb}$ versus PPDa was indicative of the development of $\mathrm{T}$ cell-mediated immune response by both groups to early BCG vaccination. As expected, in vivo reactivity to intradermal administration of antigen was associated with ex vivo antigen-induced proliferation of T-cell subsets harvested at approximately the same time. Previous research suggests that preruminant colostrum-fed calves vaccinated at an early age with BCG can develop adult-like antigen-specific responses in the cervical skin-fold test (Nonnecke et al., 2005).

Total numbers and types of cells comprising blood leukocyte populations in newborn calves frequently differ from blood leukocyte populations in adult cattle and these differences may contribute to the calf's increased susceptibility to diarrheal and respiratory infections (Chase et al., 2008). In the present study, total 
numbers of leukocytes were unaffected by treatments or age; however, granulocyte numbers were higher in all calves at wk 0 with substantially higher numbers in newborn CD calves. Elevated numbers of granulocytes in the circulation of newborn CF and CD calves have been previously reported (Clover and Zarkower, 1980; Menge et al., 1999). Although monocyte numbers were unaffected by treatments, numbers were substantially lower in all calves shortly after birth than at $7 \mathrm{wk}$ of age. Because monocytes contribute to innate immunity and are also Ag-presenting cells, increased numbers in older calves may indicate immune maturation in the preruminant calf. Total numbers of lymphocytes and percentages of $\mathrm{CD}^{+}, \mathrm{CD}^{+}, \gamma \delta \mathrm{TCR}^{+}$, and $\mathrm{B}$ cells comprising the lymphocyte population were unaffected by treatment or age. These results differ from those of previous studies showing typical age-related changes in the percentages of $\mathrm{CD} 8^{+}$cells (increase), $\gamma \delta \mathrm{TCR}^{+}$cells (decrease), and B cell (increase) (Nonnecke et al., 2003). The relatively high degree of variation associated with data in the present study may have masked potential age-related differences in T-cell percentages. In both $\mathrm{CF}$ and $\mathrm{CD}$ calves, $\mathrm{NK}^{+}$cell percentages were higher at wk 7 than at wk 0 . Interestingly, $\mathrm{NK}^{+}$cell percentages in $\mathrm{CD}$ calves were higher than in $\mathrm{CF}$ calves at both time points. Previous research suggests that the bovine neonate, like the human neonate, has a higher percentage of circulating NK cells compared with adults (Kulberg et al., 2004). Bovine NK cells can reduce numbers of $M$. bovis BCG in infected alveolar macrophages or macrophages derived from blood monocytes likely by their release of cytotoxic molecules (i.e., perforin and granulysin; Endsley et al., 2006). A subset of NK cells from the bovine neonate secretes significant quantities of IFN- $\gamma$ when exposed to BCG-infected Ag-presenting cells (Hope et al., 2002). Based on these studies, high $\mathrm{NK}^{+}$cell percentages in the newborn calves may influence immune response capacity during a period of increased risk of infection.

\section{CONCLUSIONS}

Colostrum, the only source of immunoglobulin for the newborn ruminant, provides an important and essential mechanism for transferring the immunological experience of the dam to the newborn calf. In the present study, effects of colostrum deprivation on functional aspects of the immune system of the preruminant calf, specifically those associated with development of the adaptive response to vaccination, were evaluated. Colostrum-fed and colostrum-deprived calves were vaccinated with 2 different antigens at less than $2 \mathrm{~d}$ of age to track the development of the adaptive immune response during the first 2 mo of life. Effects of colostrum ingestion on the composition and functional capacities of blood-derived immune cell populations were evaluated at the time of vaccination and during the first $7 \mathrm{wk}$ following vaccination. Results indicate that colostrum has the potential to inhibit endogenous antibody responses of the preruminant calf to early vaccination with little or no effect on cell-mediated responses. Although endogenous $\mathrm{Ab}$ responses were inhibited by colostrum, certain B-cell activities were retained. Results also suggest endogenous Ab response to early vaccination is likely antigen-dependent.

\section{ACKNOWLEDGMENTS}

The authors thank N. Eischen, A. Hall, B. Pesch, and S. Zimmerman for technical support and N. Tjelmeland and A. Moser [all from the USDA-ARS, National Animal Disease Center (NADC), Ames, IA] for animal care.

\section{REFERENCES}

Aldridge, B. M., S. M. McGuirk, and D. P. Lunn. 1998. Effect of colostral ingestion on immunoglobulin-positive cells in calves. Vet. Immunol. Immunopathol. 62:51-64.

Ametaj, B. N., D. C. Beitz, T. A. Reinhardt, and B. J. Nonnecke. 1996. 1,25-Dihydroxyvitamin $\mathrm{D}_{3}$ inhibits secretion of interferon- $\gamma$ by mitogen- and antigen-stimulated bovine mononuclear leukocytes. Vet. Immunol. Immunopathol. 52:77-90.

Bannantine, J. P., and J. R. Stabel. 2000. HspX is present within Mycobacterium paratuberculosis-infected macrophages and is recognized by sera from some infected cattle. Vet. Microbiol. 76:343-358.

Besser, T. E., and C. C. Gay. 1994. The importance of colostrum to the health of the neonatal calf. Vet. Clin. North Am. Food Anim. Pract. 10:107-117.

Blum, J. W. 2006. Nutritional physiology of neonatal calves. J. Anim. Physiol. Anim. Nutr. (Berl.) 90:1-11.

Buddle, B. M., D. N. Wedlock, N. A. Parlane, A. L. Corner, G. W. de Lisle, and M. A. Skinner. 2003. Revaccination of neonatal calves with Mycobacterium bovis BCG reduces the level of protection against bovine tuberculosis induced by a single vaccination. Infect. Immun. 71:6411-6419.

Butler, J. E. 1974. Immunoglobulins of the mammary secretions. Pages 217-255 in Lactation: A Comprehensive Treatise. Nutrition and Biochemistry of Milk/Maintenance. Vol. 3. B. L. Larson and V. R. Smith, ed. Academic Press, New York, NY.

Chase, C. C., D. J. Hurley, and A. J. Reiber. 2008. Neonatal immune development in the calf and its impact on vaccine response. Vet. Clin. North Am. Food Anim. Pract. 24:87-104.

Clover, C. K., and A. Zarkower. 1980. Immunological responses in colostrum-fed and colostrum-deprived calves. Am. J. Vet. Res. 41:1002-1007.

Crowe, J. E., Jr. 2001. Respiratory syncytial virus vaccine development. Vaccine 20:S32-S37.

Endsley, J. J., M. A. Endsley, and D. M. Estes. 2006. Bovine natural killer cells acquire cytotoxic/effector activity following activation with IL-12/15 and reduce Mycobacterium bovis BCG in infected macrophages. J. Leukoc. Biol. 79:71-79.

Endsley, J. J., J. F. Ridpath, J. D. Neill, M. R. Sandbulte, and J. A Roth. 2004. Induction of $\mathrm{T}$ lymphocytes specific for bovine viral diarrhea virus in calves with maternal antibody. Viral Immunol. $17: 13-23$

Endsley, J. J., J. A. Roth, and J. D. Neill. 2003. Maternal antibody blocks humoral but not T cell responses to BVDV. Biologicals 31:123-125.

Flynn, J. L., and J. Chan. 2001. Immunology of tuberculosis. Annu. Rev. Immunol. 19:93-129. 
Foote, M. R., B. J. Nonnecke, D. C. Beitz, and W. R. Waters. 2007. Antigen-specific B-cell responses by neonatal calves after early vaccination. J. Dairy Sci. 90:5208-5217.

Foote, M. R., B. J. Nonnecke, M. A. Fowler, B. L. Miller, D. C. Beitz, and W. R. Waters. 2005. Effects of age and nutrition on expression of CD25, CD44, and L-Selectin (CD62L) on T cells from neonatal calves. J. Dairy Sci. 88:2718-2729.

Franklin, S. T., J. M. Young, and B. J. Nonnecke. 1994. Proliferation and phenotype of bovine mononuclear leukocytes in cultures stimulated by pokeweed mitogen. J. Dairy Sci. 77:3592-3600.

Glatman-Freedman, A. 2006. The role of antibody-mediated immunity in defense against Mycobacterium tuberculosis: Advances toward a novel vaccine strategy. Tuberculosis (Edinb.) 86:191-197.

Godson, D. L., M. Campos, S. K. Attah-Poku, M. J. Redmond, D. M. Cordeiro, M. S. Sethi, R. J. Harland, and L. A. Babuik. 1996. Serum haptoglobin as an indicator of the acute phase response in bovine respiratory disease. Vet. Immunol. Immunopathol. 51:277-292.

Green, L. C., D. A. Wagner, J. Glogowski, P. L. Skipper, J. S. Wishnok, and S. R. Tannenbaum. 1982. Analysis of nitrate, nitrite, and $\left[{ }^{15} \mathrm{~N}\right]$ nitrate in biological fluids. Anal. Biochem. 126:131-138.

Hein, W. R., J. N. Shelton, M. W. Simpson-Morgan, and B. Morris. 1988. Traffic and proliferative responses of recirculating lymphocytes in fetal calves. Immunology 64:621-626.

Hope, J. C., P. Sopp, and C. J. Howard. 2002. NK-like CD8 ${ }^{+}$T cell in immunologically naïve neonatal calves that respond to dendritic cells infected with Mycobacterium bovis BCG. J. Leukoc. Biol. 71:184-194

Husband, A. J., M. R. Brandon, and A. K. Lascelles. 1972. Absorption and endogenous production of immunoglobulins in calves. Aust. J. Exp. Biol. Med. Sci. 50:491-498.

Husband, A. J., and A. K. Lascelles. 1975. Antibody responses to neonatal immunization in calves. Res. Vet. Sci. 18:201-207.

Kulberg, S., P. Boysen, and A. K. Storset. 2004. Reference values for relative numbers of natural killer cells in cattle blood. Dev. Comp. Immunol. 28:941-948.

Lyashchenko, K., A. O. Whelan, R. Greenwald, J. M. Pollock, P. Anderson, R. G. Hewinson, and H. Vordermeier. 2004. Association of tuberculin-boosted antibody responses with pathology and cellmediated immunity in cattle vaccinated with Mycobacterium bovis BCG and infected with $M$. bovis. Infect. Immun. 72:2462-2467.

McGuirk, S. M., and M. Collins. 2004. Managing the production, storage, and delivery of colostrum. Vet. Clin. North Am. Food Anim. Pract. 20:593-603.

Menge, C. H., B. Neufeld, W. Hirt, R. Bauerfiend, G. Blajer, and L. H. Wieler. 1999. Phenotypical characterization of peripheral blood leukocytes in the newborn calf. J. Vet. Med. 46:559-565.

Nonnecke, B. J., M. R. Foote, B. L. Miller, M. Fowler, T. E. Johnson, and R. L. Horst. 2009. Effects of chronic environmental cold on growth, health, and select metabolic and immunologic responses of preruminant calves. J. Dairy Sci. 92:6134-6143.

Nonnecke, B. J., M. R. Foote, J. M. Smith, B. A. Pesch, and M. E. Van Amburgh. 2003. Composition and functional capacity of blood mononuclear leukocyte populations from neonatal calves on standard and intensified milk replacer diets. J. Dairy Sci. $86: 3592-3604$.

Nonnecke, B. J., W. R. Waters, M. R. Foote, M. V. Palmer, B. L. Miller, T. E. Johnson, H. B. Perry, and M. A. Fowler. 2005. Development of an adult-like cell-mediated immune response in calves after early vaccination with Mycobacterium bovis bacillus Calmette-Guerin. J. Dairy Sci. 88:195-210.

Petersen, H. H., J. P. Nielson, and P. M. Heegard. 2004. Application of acute phase protein measurements in veterinary clinical chemistry. Vet. Res. 35:163-187.

Rajaraman, V., B. J. Nonnecke, S. T. Franklin, D. C. Hammell, and R. L. Horst. 1998. Effect of vitamins A and E on nitric oxide production by blood mononuclear leukocytes from neonatal calves fed milk replacer. J. Dairy Sci. 81:3278-3285.

Rajaraman, V., B. J. Nonnecke, and R. L. Horst. 1997. Effects of replacement of native fact in colostrum and milk with coconut oil on fat-soluble vitamins in serum and immune function in calves. J. Dairy Sci. 80:2380-2390.

Sasaki, M., C. L. Davis, and B. L. Larson. 1976. Production and turnover of IgG1 and IgG2 immunoglobulins in the bovine around parturition. J. Dairy Sci. 59:2046-2055.

Siegrist, C. A. 2001. Neonatal and early life vaccinology. Vaccine 19:3331-3346.

Smith, T., and R. B. Little. 1922. The significance of colostrum to the newborn calf. J. Exp. Med. 36:181-198.

USDA-APHIS. 2005. Service Brochure No. 91-45-011, Bovine Tuberculosis Eradication: Uniform Methods and Rules. USDA-Animal and Plant Health Inspection Service, Washington, DC.

USDA-APHIS NAHMS. 2010. Heifer calf health and management practices on U.S. dairy operations 2007. USDA-Animal and Plant Health Inspection Service, National Animal Health Monitoring System, Washington, DC.

Vordermeier, H. M., B. Villarreal-Ramos, P. J. Cockle, M. McAulay, S. G. Rhodes, T. Thacker, S. C. Gilbert, H. McShane, A. V. Hill, Z. Xing, and R. G. Hewinson. 2009. Viral booster vaccines improve Mycobacterium bovis BCG-induced protection against bovine tuberculosis. Infect. Immun. 77:3364-3373.

Waters, W. R., M. V. Palmer, B. J. Nonnecke, T. C. Thacker, C. F. Capinos Scherer, D. M. Estes, R. G. Hewinson, H. M. Vordermeier, S. W. Barnes, G. C. Federe, J. R. Walker, R. J. Glynne, T. Hsu, B. Weinrick, K. Biermann, M. H. Larsen, and W. R. Jacobs Jr. 2009. Efficacy and immunogenicity of Mycobacterium bovis RD1 against aerosol $M$. bovis infection in neonatal calves. Vaccine $27: 1201-1209$

Waters, W. R., M. V. Palmer, and D. L. Whipple. 2002. Mycobacterium bovis-infected white-tailed deer (Odocoileus virginianus): Detection of immunoglobulin specific to crude mycobacterial antigens by ELISA. J. Vet. Diagn. Invest. 14:470-475.

Whelan, A. O., D. C. Wright, M. A. Chambers, M. Singh, R. G. Hewinson, and H. M. Vordermeier. 2008. Evidence for enhanced central memory priming by live Mycobacterium bovis BCG vaccine in comparison with killed BCG formulations. Vaccine 26:166-173. 